University of Wollongong

Research Online

Faculty of Business - Papers (Archive)

Faculty of Business and Law

2012

Reforming the power sector in transition: Do institutions matter?

Rabindra Nepal

University of Wollongong, rnepal@uow.edu.au

Tooraj Jamasb

Heriot-Watt University

Follow this and additional works at: https://ro.uow.edu.au/buspapers

Part of the Business Commons

Research Online is the open access institutional repository for the University of Wollongong. For further information contact the UOW Library: research-pubs@uow.edu.au 


\title{
Reforming the power sector in transition: Do institutions matter?
}

\begin{abstract}
This paper aims to investigate the often poorly explored link between power sector reforms and wider institutional reforms in the economy across different groups of transition countries. We use panel-data econometrics based on bias corrected dynamic fixed effect analysis (LSDVC) to assess the impact of reforms on macroeconomic and power sector outcomes. The results indicate that power sector reform is highly inter-dependent with wider reforms in other sectors of the economy. The findings indicate that failure to harmonize inter-sector reforms leads to power sector reform measures being ineffective. We conclude that the success of power sector reforms in developing countries largely depend on the extent to which they synchronize inter-sector reforms in the economy.
\end{abstract}

\section{Keywords}

do, reforming, sector, institutions, transition:, power, matter?

\section{Disciplines}

Business

\section{Publication Details}

Nepal, R. \& Jamasb, T. (2012). Reforming the power sector in transition: Do institutions matter?. Energy Economics, 34 (5), 1675-1682. 


\title{
Reforming the Power Sector in Transition: Do Institutions Matter?
}

\author{
Rabindra Nepal \\ Department of Economics, Heriot-Watt University \\ Tooraj Jamasb \\ Department of Economics, Heriot-Watt University
}

\begin{abstract}
:
This paper quantitatively explores high-level links between power sector reforms and wider institutional reforms in the economy for a set of 27 diverse countries in rapid political and economic transition since 1990. Panel-data econometrics based on bias corrected dynamic fixed effect analysis (LSDVC) is performed to assess the impact of reforms on macroeconomic and power sector outcomes. The results indicate that power sector reform is indeed a more complicated process than initially perceived. The results also show that power sector reform is greatly inter-dependent with reforms in other sectors in the economy. We conclude that the success of power sector reforms on outcomes in developing countries will largely depend on the extent in which countries are able to synchronize inter-sector reforms in the economy.
\end{abstract}

Keywords Power sector, institutions, reforms, transition economies

JEL Classification $\quad$ C33 E02 P28 Q4

Acknowledgement :

We would like to thank Paul Hare, Mark Schaffer, Anupama Sen, an anonymous referee and participants at Heriot-Watt Economics seminar for their helpful comments. All remaining errors remain the sole responsibility of the authors. 


\section{Introduction}

The early 1990s brought about fundamental changes in economic and political settings among the popularly termed 'transition economies' (TECs hereafter) comprising twenty-nine countries ${ }^{1}$ of Central and Eastern Europe and the Former Soviet Union (FSU). The end of central planning paved the way towards implementing economy wide market-oriented reforms in the TECs as a part of pervasive political and economic changes. The pace and order of economy-wide reforms markedly varied across the TECs primarily reflecting the constraints on any government's ability and resources. Some countries such as Lithuania, Russia and Slovak Republic opted for instant large scale privatisation without appropriate legal framework as a 'shock therapy' which often resulted in significant economic and social costs. Elsewhere, civil wars and ethnic conflicts in Macedonia, Bosnia and Herzegovina, and Tajikistan disrupted and delayed the gradual progress in the transiton process in these countries. While the incentive to join the European Union and benefit from regional integration provided impetus to sectoral reforms in countries across Central and Eastern Europe in the early 2000s; the isolated Asian economies in the CIS region are still reeling under the legacy of central planning with low political commitment to sectoral reform since independence.

The systemic change of early 1990's coincided with rising popularity of power sector reforms around the world. Furthermore, the power sector was also the unanimous choice (or target) across the TECs to rapidly undergo the scissors of marketization for two major reasons: a) the economy as a whole was highly subsidized through unusually low power prices prior collapse and $b$ ) the direct and indirect contribution of the power sector towards the country's Gross Domestic Product (GDP) ${ }^{2}$, the national strategic aspects of supply security coupled with mass politicisation and natural monopoly characteristics of the sector meant that the role of the power sector was crucial in determining the fate of economic reforms (in terms of speed

\footnotetext{
${ }^{1}$ The countries included can be divided into three distinct groups: Central Eastern Europe and Baltic States (CEB) comprising Croatia, Estonia, Hungary, Latvia, Lithuania, Poland, Slovak Republic and Slovenia; South-Eastern Europe (SEE) comprising Albania, Bosnia and Herzegovina, Bulgaria, FYR Macedonia ,Serbia, Romania and Montenegro; Commonwealth of Independent States (CIS) comprising Armenia, Azerbaijan, Belarus, Georgia, Kazakhstan, Kyrgyzstan, Moldova, Russia, Tajikistan, Turkmenistan, Ukraine and Uzbekistan. Besides these countries, Turkey and Mongolia are also included in the group of transition economies as per European Bank of Reconstruction and Development (EBRD) areas of operation.

${ }^{2}$ For instance, the oil and gas exports for Turkmenistan and Azerbaijan constituted $68.7 \%$ and $30.7 \%$ of GDP respectively in 2000. See Table A in Appendix I.
} 
and order) for countries experiencing drastic systemic changes. Thus, the role of power sector can be perceived to be pivotal in economic growth policies of the TECs.

Two decades have passed by since the mass-experiment of market-based reforms swept across the power sectors of TECs. Yet, the current status of power sector reform in these countries is described as being one of mixed outcomes, stalled reforms and uncertainty (Williams and Ghanadan, 2006). Partly, the present state of the power sector across TECs is reminiscent of the fact that the collapse of central planning was not a choice of any country or government but rather a consequence of dysfunctional political and economic system of yesteryears. Belarus and the Caspian countries (e.g. Turkmenistan) have exhibited the greatest reluctancy towards power sector reform as these countries have not even started with the initial reform process of liberalization, small scale privatization and the creation of an environment supportive of private investment. Largely, it also reflects the failure of sure-fire recipes of western advisors to cater to the local taste in the process of quick transition to a market economy (Stiglitz, 1999). Several new European Union (EU) member states like Hungary and Bulgaria though nearing the advanced phase of power sector reforms still experience chronic power shortages, high distribution losses, lack of investments and vulnerability of energy supply. Thus, it is debatable whether the reforming countries have significantly benefited from power sector reforms than the non-reforming ones. Likewise, it is also worth pondering is if the energy-rich countries like Kazakhstan, Azerbaijan, Russia, Turkmenistan and Uzbekistan benefited from power sector reforms since 1990 relative to non-energyrich transition economies with a gradual real increase in energy prices since reforms.

It is tacitly agreed among policymakers that the power sector reforms in the transition economies has proven to be difficult and complicated on-going process (Jamasb et al. 2004). The current sectoral performance portrays that formulated policies did not effectively understand the functioning of a market economy coupled with the misunderstandings of the reform process itself that largely failed to take country-specific conditions into account. Hence, the empirical evidence of electricity market reforms has starkly defied the logic of reforms. The success of marketoriented electricity reforms can tremendously depend on the development of market-based institutional framework to support reforms (Hogan, 2001). So, similar approaches to power sector reform have led to utterly different outcomes in TECs depending upon the formal and informal institutions existing in each country (Hirschhausen and Wadel, 2001). The experience with following a standard menu of reform based on OECD experiences (primarily the UK and Norway ${ }^{3}$ ) has backfired as electricity reform in the TECS is different from OECD reform in terms of reform

\footnotetext{
${ }^{3}$ Chile is the only non-OECD country that experienced a successful electricity reform process since the start of the reform in the early 1980s and is considered to be a pioneer in power sector reform.
} 
drivers, sectoral aspects and institutional context. Policymakers for a large period failed to understand that electricity reform in the TECS is not an undertaking confined to the sector but closely interlinked with problematic legal and institutional contexts throughout the economy (Williams and Ghanadan, 2006).

This paper aims to qualitatively and quantitatively assess the often poorly explored link between power sector reforms and wider institutional reforms in the economy across different groups of the transition countries. We study the link via the impact of power sector reforms on the economic, technical and environmental aspects of power sector also accounting for the interactions between power sector reforms and economy-wide sectoral level institutions since 1990. By doing so, the paper attempts to examine the role of country-level institutional structure and framework in explaining why some power markets work and some do not based on the 'New Institutional Economics (NIE) $)^{4}$. The contributions of this paper are two-fold. Firstly, the lessons learnt from two decades of massive irreversible reform experiment can provide valuable insights to the power sector reforms of other developing and less developed countries in Asia and Africa where 'economic transition' is on-going. Secondly, this paper contributes to the relatively scarce literature on the quantitative analysis of power sector reform across the TECs using panel-data econometrics.

The paper is planned as follows. Section 2 of the paper continues to assess the literatures encompassing the relationship among different sectoral level institutions in the economy and power sector reforms. Section 3 explains the drivers of power sector reform in TECs along with a background of the power sector prior and after reforms. In section 4, the data and relevant econometric methodology is discussed. Section 5 presents, discusses and summarizes the results while section 6 concludes with relevant policy recommendations.

\section{The relationship between country level institutions and power sector reforms}

Although the neoclassical economic theory considers both competition and privatization as the core aspects of a market economy; the outcomes cannot be guaranteed to be Pareto efficient in the absence of proper institutional infrastructure (Rodrik et al. 2004). North (1971) has criticized the standard neoclassical theory as it rejects the role of institutions and time. The early phase of the systemic change rested on the notion that market-oriented policies would automatically install the institutions of a market-based economy during the

\footnotetext{
${ }^{4}$ The term 'NIE' was first coined by Williamson (1975). As per North (1971) who is considered as one of the founding fathers of institutional economics, NIE has two major strands: a) institutional environment (so called rules of the game which can be explicit, formal or implicit, informal) and b) institutional arrangements by contrast are specific guidelines-the so called 'governance structures' (Williamson, 1996).
} 
transition process. This led to a decade long of neglecting institutional difference across countries in implementing power sector reforms (Hirschhausen and Waelde, 2006). Stiglitz (1999) argues that the enforcement mechanisms of reforms (including power sector reforms) were weak as the state's legal and judicial capacities were limited during the transition process brewing inefficient rent seeking and corruption with shock therapy reforms (such as large scale privatization). Empirical econometric studies by Heybey and Murrell (1997) have concluded that the success of sectoral reforms on outcomes in any transition economy depends much more on the overall institutional framework than on short-term policies. Bacon and Besant-Jones (2001) found evidence of country policy and institutions being positively correlated with reform while country risk being negatively related with reform. Rufin and Rangan (2004) using institutional explanatory variables with electricity reform scores found an ambiguous and insignificant relationship between judicial independence and competition.

The role of broad and sectoral level institutions as a key element to properly understand a market-based economy was also overlooked in TECs. Arrow (1972), Hirschmann (1992), Putnam (1993), Fukuyama (1995), Stiglitz (1999) and others have argued that the success of market-oriented economy cannot be understood in terms of narrow economic incentives such as prices but norms, institutions, social capital and trust play critical roles. Pollitt (2009) in relation to the South Eastern Europe (SEE) electricity markets concludes that power reform is a part of wider institutional reforms and successful electricity reforms cannot be achieved unless there is sufficient economy-wide institutional reform to reinforce power sector reforms. Based on Levy and Spiller (1996), Kennedy (2003) also underscores the importance of having a proper institutional context for regulation (for example whether or not a regulator is politically independent ${ }^{5}$ ) for power sectors reforms to produce its desired consequences.

Following Easterly and Levine (2003), two relevant views are drawn and hence studied in this paper on the relationship between overall institutional development and power sector reforms. The first view holds that electricity sector reform's major effect on electricity sector performance works through long-lasting institutions. Economies where reforms are most effectively implemented are able to do so by adapting to the required political and legal changes through suitable institutional development ${ }^{6}$. The second view maintains that power sector reforms and

\footnotetext{
${ }^{5}$ The criteria vary when assessing whether a regulator can be considered independent or not. The widely used criteria are the nature and terms of regulatory appointment, source of funding of the regulatory body and the extent of participation of the regulators in designing regulatory content such as tariff methodology. Please see Stern (1997), (1998) for a detailed discussion.

${ }^{6}$ This means that the role of technology is endogenous to the institutions as the necessary arrangement for the adoption of better technology works through reforms necessitated.
} 
institutions should reflect current know-how and political conditions of the power sector. This means that any changes in knowledge on reforms and institutions suitable for improved performance of the power sector or changes in political objectives should translate to quicker changes in institutions and reforms ${ }^{7}$.

\section{Motives and Contexts of Power Sector Reform in TECs}

Though reform was inevitable and much needed in the power sector of TECs; factors external to the power sector played a major role to catalyse the electricity sector reform process. For example, Hungary pursued power sector reform in order to reduce the fiscal deficit while for Czech Republic and Russia; reforming power sector was vastly a part of overall ownership change. The most important factor was the limited state finance and unsustainable burdens on state budgets to finance the sector with short-run excess capacity (Williams and Ghanadan, 2006; Bacon and Besant Jones, 2001, Joskow 1998). While economic efficiency, competition and choice were the main drivers of electricity deregulation reform in the developed economies (such as OECD); these aspects were secondary to drive electricity reform process in the TECs ${ }^{8}$. The oil shocks of the 1970s led to soaring foreign debt, huge budget deficits and high inflation forcing the government of the state-led model in the TECs to implement economy wide structural adjustment programs in mitigating the macroeconomic and fiscal crisis. The power sector including other state-led utilities was favoured candidate to undergo restructuring as these sectors had the greatest potential for revenue generation through corporatization and privatization. Hence, power sector reforms for cost recovery and private investment followed suit as an alternative source to finance the sector and raise government revenue (Jhirad, 1990).

International financial institutions such as the World Bank, the Asian Development Bank (ADB), EBRD, and the Inter-American Development Bank (IADB) also played a role to initiate power sector reforms as the economic stabilization loans came with strings attached to reform the power sector in the TECs (Bacon and Besant-Jones, 2001). Furthermore, as of early 2000 the prospect of EU accession has had a significant influence on the extent of power sector reforms in many CEB and SEE countries in the region (EBRD, 2001). Following Jamasb et al. (2004), the motives behind power sector reforms in the TECs is summarised in table 1 in terms of 'push' and 'pull' factors.

\footnotetext{
${ }^{7}$ The second view is in line with North (1994) which includes the role of time in understanding the operation of markets.

${ }^{8}$ A number of studies have been carried out to assess the impacts of reform concerning developed countries. Please see for example Steiner (2001), Hattori and Tsutui (2004) to study the empirical evidence of power sector reforms on performance for OECD countries.
} 


\begin{tabular}{|c|c|}
\hline Push Factors & Pull Factors \\
\hline $\begin{array}{l}\text { Macroeconomic events: } 1970 \text { oil crisis, } \\
\text { Post-Soviet economy-wide market-based } \\
\text { transition (1989), Asian Financial crisis } \\
\text { (1997-1998), economy-wide } \\
\text { liberalization and reform programs as } \\
\text { initiated by the fiscal crisis }\end{array}$ & $\begin{array}{l}\text { Capital raising options: privatization of } \\
\text { state assets, Greenfield private } \\
\text { investment }\end{array}$ \\
\hline $\begin{array}{l}\text { Limited national fiscal ability: high public } \\
\text { debt, utility borrowing as a major } \\
\text { proportion of national debt }\end{array}$ & $\begin{array}{l}\text { Lending for institutional reform: } \\
\text { macroeconomic stabilization lending } \\
\text { conditional upon power sector } \\
\text { restructuring, asset privatization (IMF), } \\
\text { liberalisation and reform for new power } \\
\text { sector loans (World Bank in 1993) }\end{array}$ \\
\hline $\begin{array}{l}\text { OECD Deregulation: new energy } \\
\text { multinationals created as a result of } \\
\text { OECD energy sector deregulation, } \\
\text { provided investment opportunities for } \\
\text { Europe and USA }\end{array}$ & $\begin{array}{l}\text { Spill-over effects from international } \\
\text { experiences: learning from pioneering } \\
\text { reforms of power sectors in Chile, } \\
\text { England and Wales and Norway in the } \\
\text { 1980s and early 1990s }\end{array}$ \\
\hline $\begin{array}{l}\text { Investments constraints of the power } \\
\text { sector: no ability to self-finance, system } \\
\text { upgrading and modernization required, } \\
\text { high projected electricity demand }\end{array}$ & $\begin{array}{l}\text { EU accession: opportunities to benefit } \\
\text { from regional integration by reforming } \\
\text { the power sector in accordance to the EU } \\
\text { Directives }\end{array}$ \\
\hline
\end{tabular}

Table 1: Drivers of power sector reforms in TECS

Source: Own Compilation

The early phase of reform policies were predominantly based on the theoretical analysis and policy recommendations of economic advisors influenced by electricity sector deregulation experiences in Europe and USA. A typical standard menu of reform for the TECs and non-OECD countries was prescribed by the World Bank through the reform 'scorecard' (World Bank, 1999). The major elements of the menu followed a gradual progression from forming energy laws to sector corporatization and commercialization with an independent energy regulator in place that eventually led to sector restructuring and privatization (see Jamasb, 2004). The creation of competitive wholesale markets was the last step to fully complete the reform process as outlined in the scorecard. While the creation of a spot market or pool was one of the most innovative reforms of privatization in the power sector of the TECs; it needs to be examined whether it led to cost-reflective bidding (Newberry, 1994). 
However, the 'scorecard' as well as earlier power sector reform programmes is criticized on the grounds that the local contexts were thoroughly ignored and not reflected (Bacon and Besant-Jones, 2001). The focus of the standard menu of reforms was primarily financial with societal concerns such as access, service quality, socially efficient pricing and environment being ignored (Williams and Ghanadan, 2006) $)^{9}$. Fyodor Dostoevsky, the famous Russian novelist in his book 'The Brothers Karamazov', wrote 'There you have it-reforms on unprepared ground, and copied from foreign institutions as well-nothing but harm'. His insight to a large extent can be applicable to the power sector reforms ${ }^{10}$ in TECs and is a matter of empirical investigation under section 5 of this paper. Meanwhile, the subsection below highlights the economic, technical and environmental aspect of power sector status before and in the early process of transition process.

\subsection{Power sector status before and in the early stages of reform}

The power sector of economies in transition in the Former Soviet Union and Central and Eastern Europe at the beginning of the reform period had some common characteristics in terms of the economic, technical and environmental aspects of power generation. They are described as below:

a) Declining national GDP: As already mentioned, bailing out the economy with sinking GDP as an aftermath of the oil crisis of 1979 and 1980s was one of the objectives of the economic reforms in TECs. Reforming the power sector thus was considered appropriate by the transition countries as a major way to recover from the fiscal crisis. The contractions in real GDP during the early reform phase in Central Europe were comparable to the $20 \%$ fall in the US during the Great Depression while for other CEE and CIS economies the fall was even higher (Stern and Davis, 1997). Though the causality is not clear, the fall in GDP can be attributed to a major fall in energy consumption significantly lowering the industrial output and vice-versa. Table B in appendix I shows the annual percent change in regional GDP (1990 as the base year) and energy consumption from 1990 to 1994. It is apparent from table $B$ that that energy consumption declined at a similar fashion to the decline in GDP by around 18\% in 1990-1993. Elsewhere for Russia and FSU, the decline in GDP was more severe than the drop in energy demand.

Figure 1 below traces the per capita GDP path of the CEB, SEE and CIS countries from 1990-2008. All country groups experienced a recovery after the Asian financial crisis

\footnotetext{
${ }^{9}$ Esatche et al. (2002) have also addressed these issues in the Latin American context as a part of wider institutional reform context.

${ }^{10}$ Pittman (2003) uses Dostoevsky's witticism to analyse the speed and success of reforms of the infrastructure sectors in transition economies.
} 
although the CEB region had experienced the greatest slump. The reason could be because the CEB region includes 7 out of 9 countries in the EU with a strong industrial base that was hard-hit by declining energy consumption. All countries experienced a significant fall in per capita GDP during the early phase of transition.

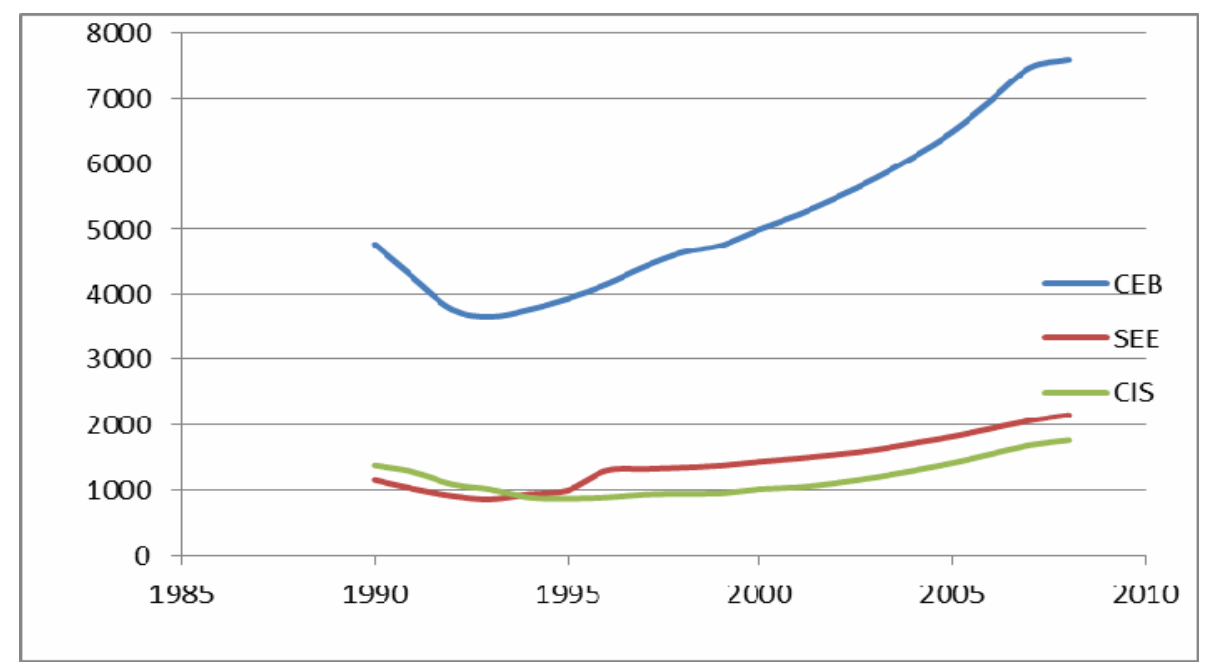

Figure 1: Per capita GDP across the TECs from1990-2008 in US dollars (constant 2000)

Source: Own compilation

Given an established relationship between GDP and energy consumption; the power sector reforms in the TCECs should have significantly affected the per capita national GDP over-time.

Hypothesis 1: Power sector reforms and wider economic institutional reforms in the economy bear significant results in the overall national GDP among the TECS.

b) Short-run excess capacity: Although the region had ample capacity; the breakup of the Soviet Union also broke the integrated energy supply system allowing the oil and gas prices to rise as par to the international levels. The hike in energy prices produced an energy price shocks in the oil importing countries. Energy supply from other FSU producers such as Kazakhstan and Turkmenistan also experienced frequent disruptions with the Russian monopoly over export routes through Ukraine, Slovakia, and the Czech Republic. Hence, due to security of supply concerns and to avoid the harsh rise in oil prices; countries might have been tempted to add additional generation capacity through meaningful power sector reforms in the lurch towards reducing energy dependency.

As of 1989, numerous nuclear reactors in Armenia, Bulgaria, Lithuania, Russia, Slovakia and Ukraine had an installed capacity of 300 gigawatts (Gray, 1995). With time, several unsafe nuclear plants were shut down (for e.g Chernobyl in Ukraine in 
2001). With demand for electricity rising in particular and supply security being increasingly threatened, the early experience of excess capacity is thought to be over by now (EBRD, 2008). Figure 2 below shows the gross generating installed capacity in the CIS region has been increasing post $\mathbf{2 0 0 0}$ while the figures are fairly stable in the SEE since 1991.

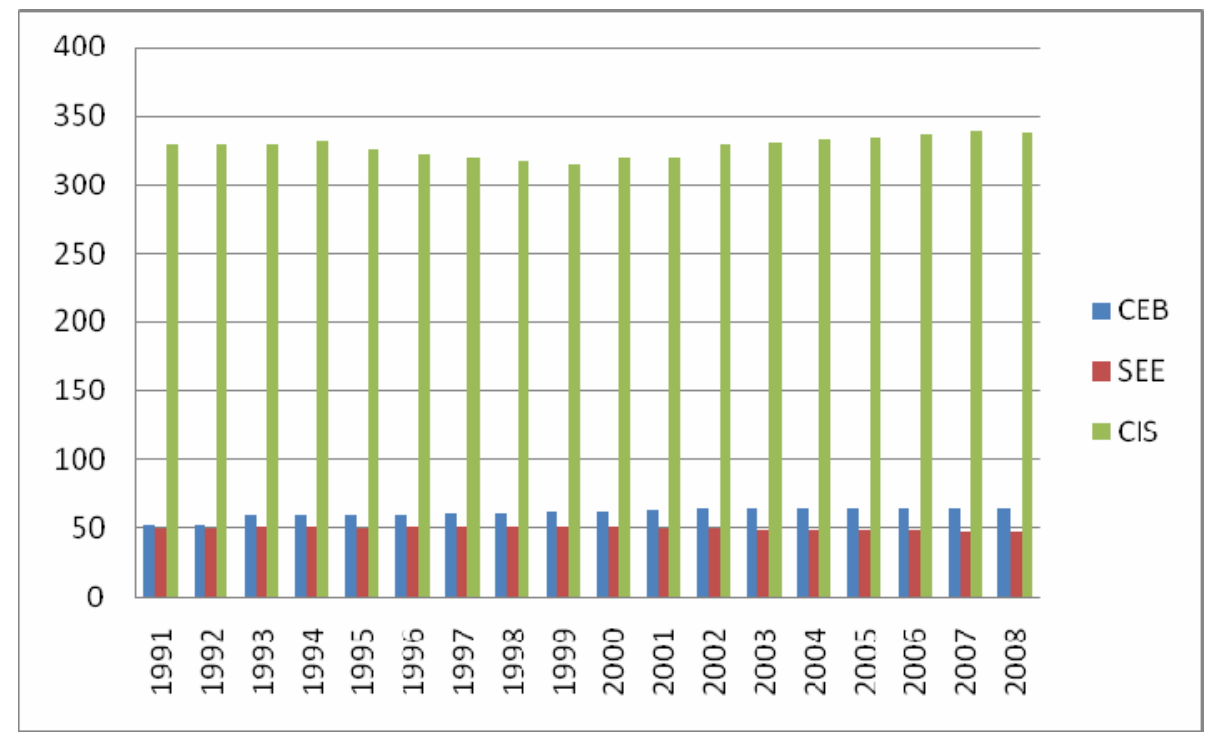

Figure 2: Gross generating installed capacity from1991-2008 ( million Kilowatts)

Source: Own compilation

Hypothesis 2: Power sector reforms and economy-wide institutional reforms can enhance overall capacity in generation in the TECs and improve the supply security.

Similarly, it is likely that increasing environmental obligations ${ }^{11}$ and incentives over the years have prompted the transition countries to expand their renewable energy base. The phasing out of the unsafe nuclear plants and motives to reduce the emissions from the use of dirty coal could have induced investments in renewable generation capacity in the transition regions. The transition towards a less carbon intensive economy combined with the need to meet the increasing electricity demand should have prompted countries to invest more in renewable capacity expansion. Figure 3 shows that thermal generation dominated the nuclear and renewable generation capacity across the transition countries in 2007.

\footnotetext{
${ }^{11}$ This might especially be the case for those countries that joined or are in the process of joining EU to match the environmental standards as expected by the EU.
} 


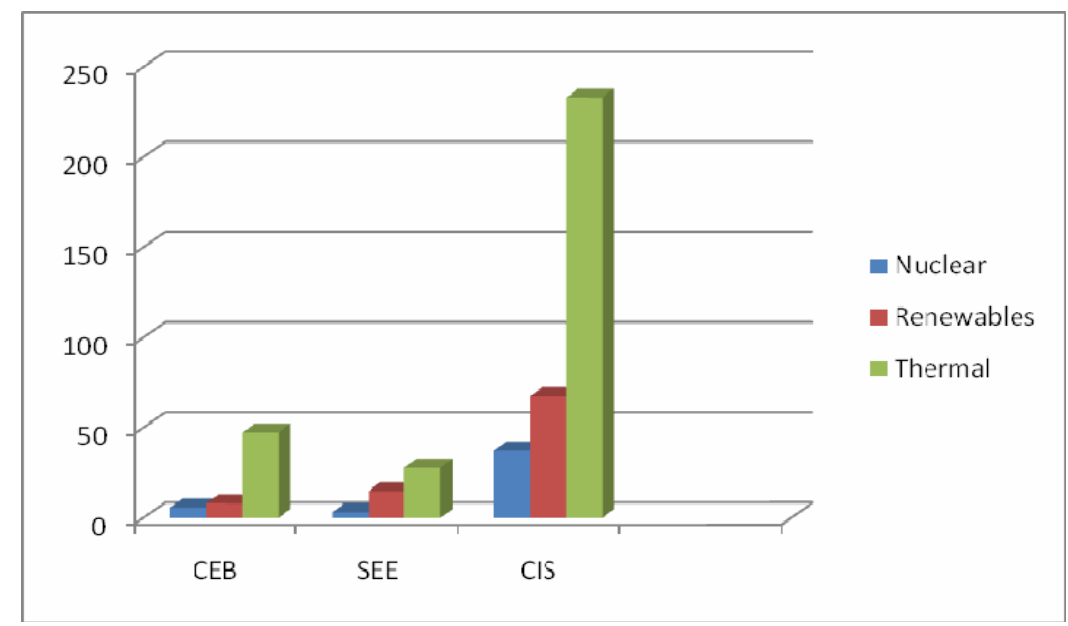

Figure 3: Capacity mix in 2007 across TECS

Source: Own compilation

Hypothesis 2.1: Power sector reforms and economy-wide institutional reforms can enhance overall renewable capacity in generation across the TECS over-time.

c) Low and distorted electricity prices and high power losses: Before reforms started in 1990, energy prices in the transition economies were majorly de-aligned from economic cost with tax revenue being used to subsidize various consumption groups including households. The price structure was also distorted as low household prices were achieved by charging relatively higher prices for industrial users (so called cross-subsidisation). But, the practice of lower prices of electricity and to households in particular seems to have been maintained during the transition period as illustrated by table $D$ in appendix I.

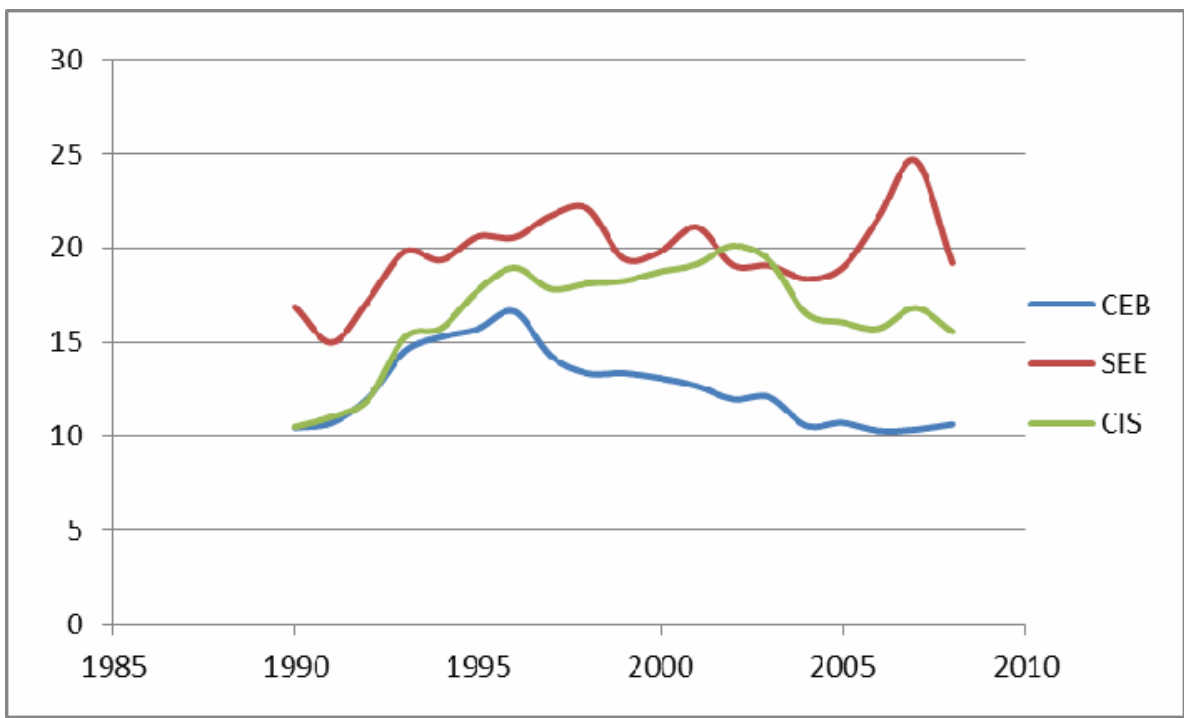

Figure 4: Transmission and Distribution losses across TECs (in \% of total output) Own compilation 
The experience of few TECs from Table D suggests that the practice of low electricity prices and price distortion through cross-subsidies is largely prevailing in the CIS countries with twin problems of low bill collection and high commercial losses ${ }^{12}$. The low power prices has been a major setback in terms self-supporting the system by generating investment for capacity and grid expansion/maintenance culminating to high levels of transmission and distribution losses.

Hypothesis 3: Power sector reforms and institutional reforms in the economy are thus expected to have increased the electricity prices over time and hence minimised cross subsidies, commercial and non-commercial (technical) losses while maximizing bill collection across these countries.

However, the lack of sufficient data on prices and commercials losses has confined the above hypothesis to be tested only in terms of the technical losses. Figure 4 reports the technical losses as a percentage of total power output across the TECs. The losses remain the lowest on average in the CEB region and the highest in the SEE region. For example, Albania belonging to the SEE region had the losses reaching $69 \%$ of output produced in 2006 . The high level of losses could indicate the poor state of the transmission and distribution networks in need of maiantence and upgrading and hence a major technological constraint. On the other hand, the high technical losses also demonstrate the lack of investments in the network infrastructures to upgrade and maintain them. The lower power prices also imply that the power sectors across TECs is unable to raise the required capital and thus making them incapable of supporting the system.

d) Changing Patterns of Electricity Production: Lenin declared in 1920 that 'Communism is Soviet power plus the electrification of the whole country'. The importance of the power sector to the economy was thus reflected in higher electricity production before reform after which electricity production seems to have declined due to declining consumption under economic slowdown. The fall in national GDP (see figure 1) across the TECs after reform leading to lower electricity demand might have lowered the electricity production. Figure 5 shows the nature of declining power production for the CIS region during the early phase of transition process with power production picking up after 2000. The Asian financial crisis seems to have negatively affected the CIS region the most in terms of power production. $\mathrm{A}$ decisive factor is the declining industrial demand for electricity among the energyintensive industries during this period.

\footnotetext{
${ }^{12}$ Bill collection is defined as the ratio of cash collected to the total amount billed while commercial loss is defined as the non-billed consumption through illegal connection meter tampering and theft (so called non-technical losses).
} 


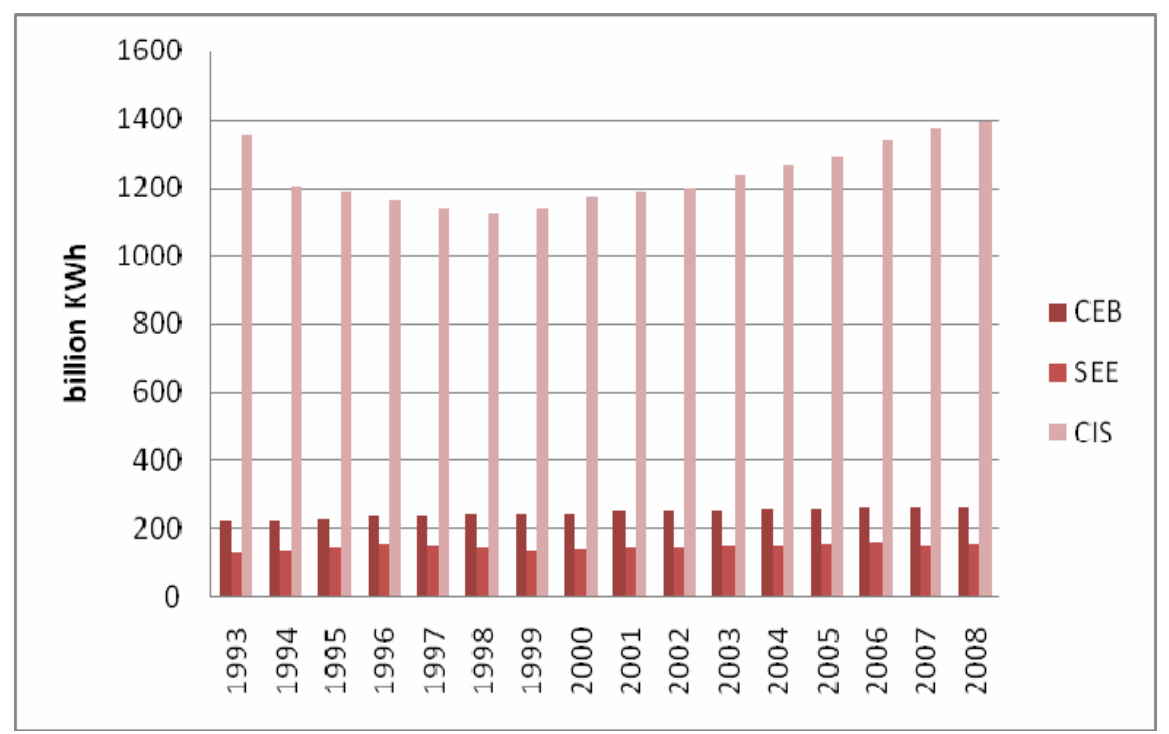

Figure 5: Electricity Production across TECs (KWh) from 1993-2008

Source: Own compilation

The numbers on net electricity imports in Table $\mathrm{C}$ (see Appendix I) also confirms that electricity consumption in particular for Hungary and Poland fell sharply as compared to electricity production during the early period of transition. The SEE region at present as a whole is a net importer of electricity. However, the increasing emphasis on regional market integration under excess capacity could encourage more electricity production and benefit from it accordingly.

In an ideally functioning power market, power production should respond to power demand largely reflecting the efficiency of power sector reforms and other institutional changes in the economy.

Hypothesis 4: Power sector reforms and economy-wider institutional reforms can vary the overall volume of electricity production in an economy.

Similarly, the increasing importance on mitigating climate change impacts as a part of broader energy policy goals by reducing carbon emissions combined with a need to improve supply security could have increased the renewable energy production across the transition regions. Figure 6 shows that electricity production in the CEB, SEE and CIS region from different energy sources in 2007. The SEE region has the largest renewable electricity production though thermal electricity production dominates all regions. The CEB region produced the least amount of electricity from nuclear sources (around 9\%). 


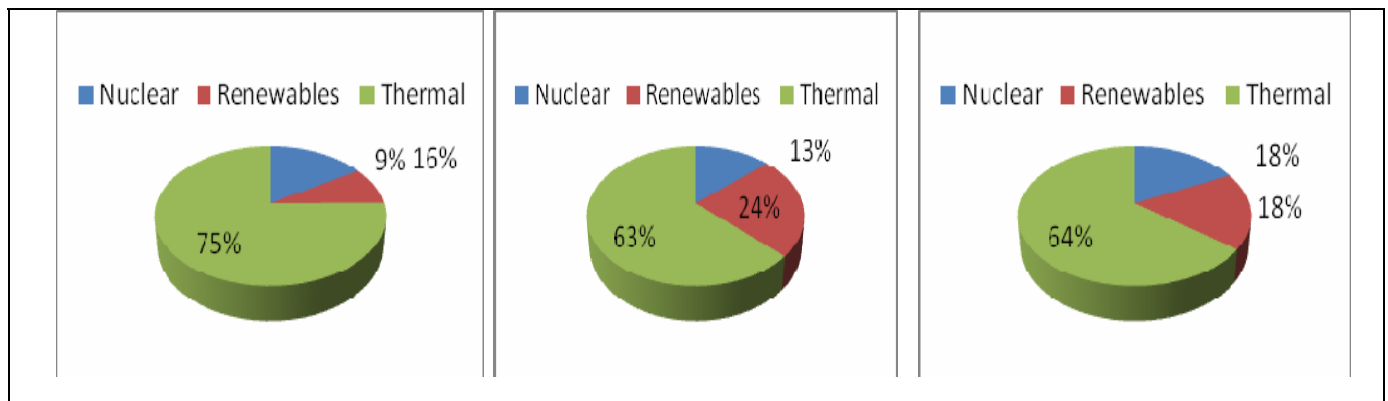

Figure 6: Electricity production by fuel types for CEB, SEE and CIS respectively (2007)

Source: Own compilation

Hypothesis 4.1: Power sector reforms and economy-wider institutional reforms can increase the overall volume of electricity production from renewable sources in the transition countries.

e) High Energy Intensity: Historically, the energy consumed per unit of GDP in the transition economies was estimated at four to eight times that of OECD countries and the United States (Gray, 1995). The high energy intensity of the yesteryears can be primarily attributed to the presence of many energy intensive industries and the inefficiency of energy use spurred by lower power prices. Furthermore, the distorted energy prices as discussed above and the soft budget constraints for industry (for e.g. being debt free) also led to high energy use in the TECs. Figure 7 shows that CIS countries such as Uzbekistan and Turkmenistan where electricity prices are very low (see table $D$ in appendix I) also have high energy intensity of GDP.

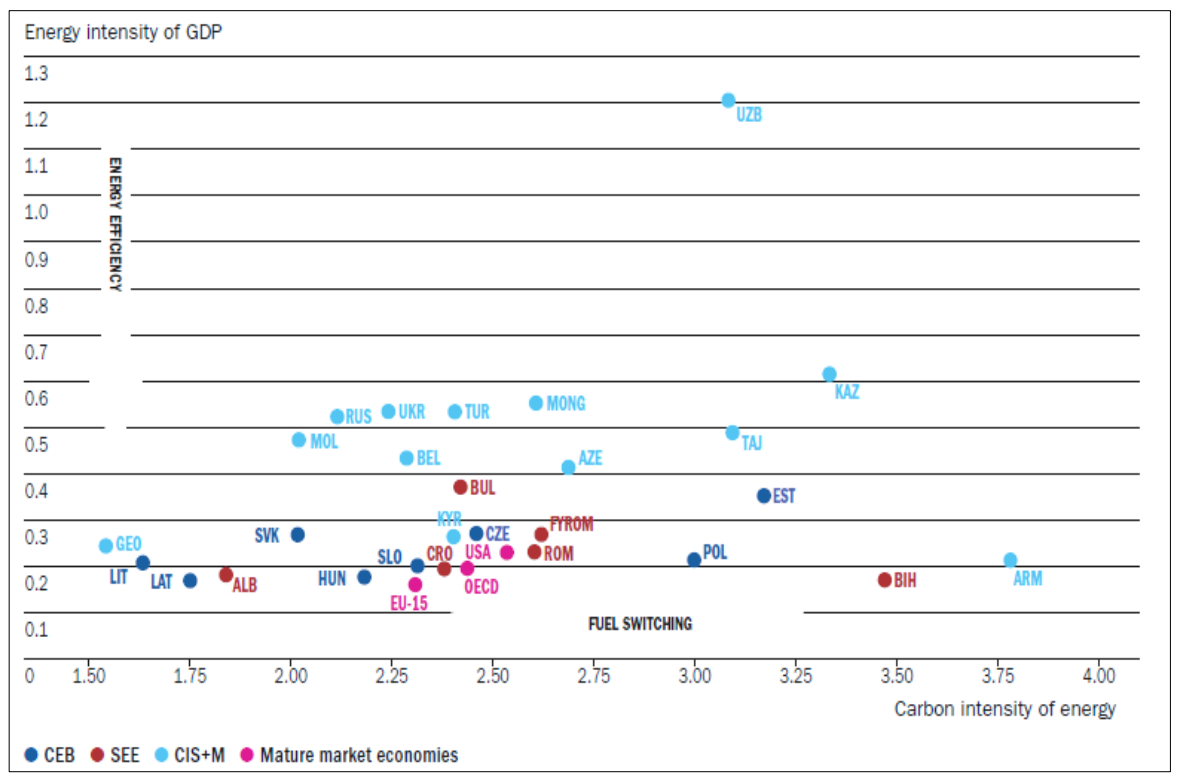

Figure 7: Energy intensity of GDP versus Carbon intensity of GDP in TECs Source: Adapted from EBRD (2008) 
According to EBRD (2008), the CIS countries being the most energy intensive of all have reduced their energy intensity by about one-third since 1994 . However, these countries still use three times more energy as compared to Western Europe to produce a unit of GDP in terms of purchasing power parities (PPP). Hence, there is a significant potential in the TECS to be more energy efficient and eventually converge at a similar levels with the OECD countries in terms of per capita consumption of electricity.

Hypothesis 5: Power sector reforms and reforms of overall institutions in the economy can reduce the overall energy intensity of GDP across the TECs.

f) High Carbon Emissions Intensity: In the past, many CEE and FSU countries relied heavily on low-quality and high polluting coal and lignite. While reliance on coal and lignite was an alternative towards not being utterly dependent on Russian oil and gas; it also meant high levels of carbon and sulphur emissions. For example, coal comprised of $90 \%$ of all fuel used for power generation in Poland and $60 \%$ in the former Slovakian Republic in 1995 (Gray, 1995). Figure 8 show that the transition countries met $6 \%$ of its total energy consumption from renewable sources in 1999. While the CEB and SEE countries consumed 7.5 mtoe of renewable energy; the number was 57.5 mtoe for CIS countries.

Of the world's 20 most carbon intensive economies, 13 countries belonging to the TECs fall under this category (EIA, 2005). Kazakhstan and Russia are among the top 15 carbon polluters (CDIAC, 2005). Among all the countries in the United Nations Framework Convention on Climate Change (UNFCC), Kazakhstan, Ukraine and Uzbekistan are the three most carbon intensive economy. Figure 7 also confirms that there is significant scope for the TECs (especially the CIS countries including Mongolia) to reduce the overall amount of carbon in the economy through fuel switching and being more energy efficient which necessarily stems from appropriate power sector reforms at a first place.

Hypothesis 6: Power sector reforms and wider institutional reforms in the economy can be thus expected to reduce the overall level of carbon intensity of GDP in the TECs.

The role of electricity demand is also critical in understanding the economic, operational and environmental aspects of power sector as electricity demand directly or indirectly can shape power sector outcomes such as installed capacity, generation and network investments, technical losses, energy intensity, carbon intensity and overall electricity generation (Figure 8). 
In well-functioning power markets, it can be expected that the power sector outcomes such as (installed capacity, network investments) responds to the market signals provided by total electricity demand ${ }^{13}$. On the other hand, the ability of the power market to respond to market signals also depend on the timing and choice of policies. The importance of electricity demand upon understanding the power sector gets increasingly heightened as electricity demand post 2000 is continuing to rise across TECs.

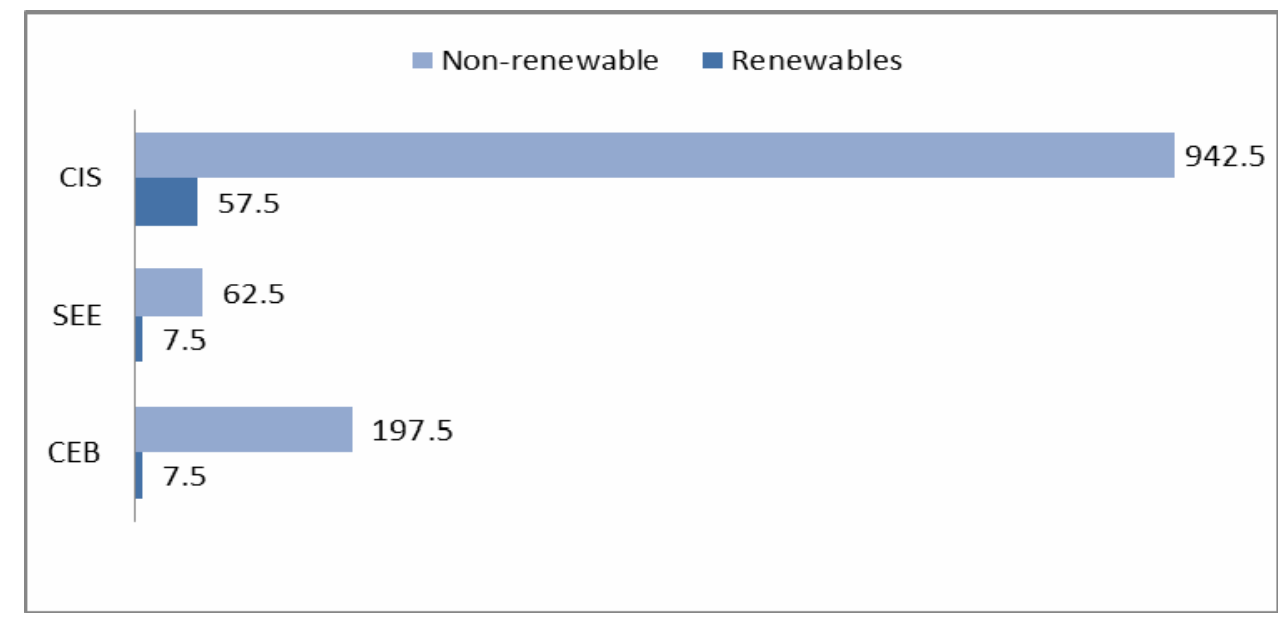

Figure 8: Total primary energy consumption in 1999/mtoe (million tonnes of oil equivalent) Source: US Energy Information Administration (EIA)

Figure 9 illustrates that the per capita electricity consumption of the TECs is eventually converging towards the levels of industrialised OECD countries. The electricity demand also significantly went low in the CIS countries including Mongolia before the onset of financial crisis until 2000. Under increasing electricity demand scenario, the aim of this paper is to test for the above formulated hypotheses in relation to the power sector reforms and the overall level of institutional development in the TECs over-time. The next section thoroughly describes the data and econometric methodology used in this study.

\footnotetext{
${ }^{13}$ In reality, total electricity demand differs from effective electricity demand as total demand can remain unmet. On the other hand, effective electricity demand should equal electricity production as what is produced is consumed and vice versa.
} 


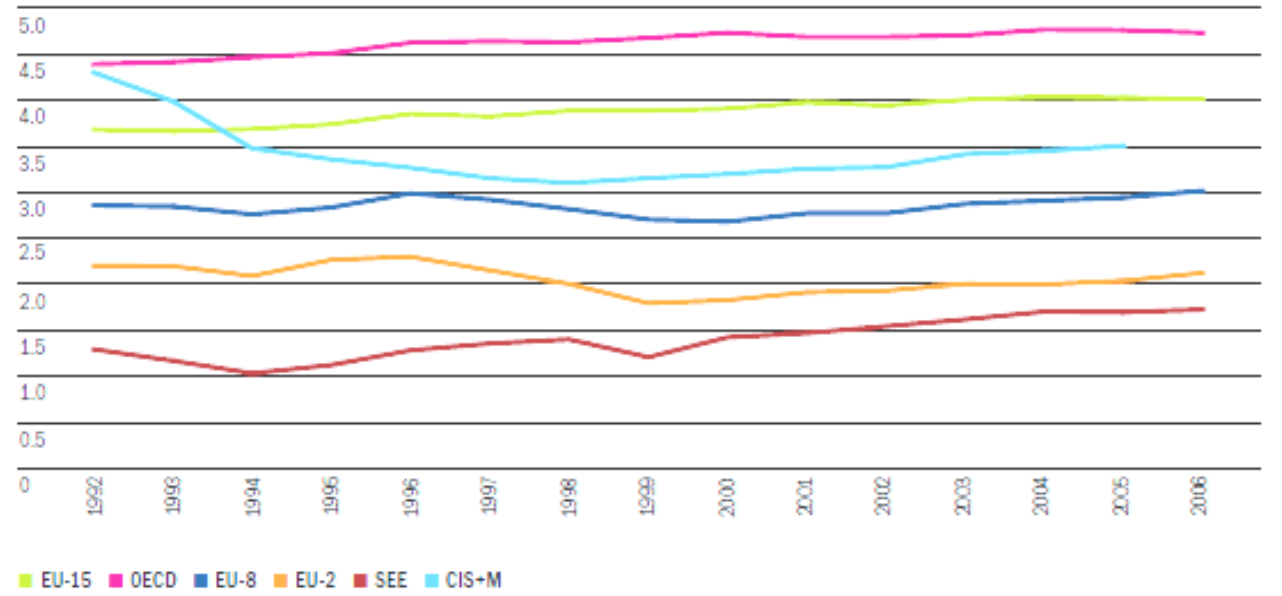

Figure 9: Per capita electricity consumption in the TECS (2007)

Source: Adapted from EBRD (2008)

\section{Data and Econometric Methodology}

The objective of this paper is to study the link between power sector reforms and wider institutional reforms in the economy since the start of the transition process (i.e. 1990 till 2008) across the TECs. Thus, it is necessary to have a comprehensive set of data that can serve as a measure of reform progress in the power sector as well as the whole economy. For this purpose, we have used the 'Transition Indicators' developed by the European Bank for Reconstruction and Development (EBRD) that measures the progress in transition through a set of transition indicators. The reform assessments are made in nine areas encompassing 1) small scale privatization, 2) large scale privatization, 3) governance and enterprise restructuring, 4) price liberalisation, 5) trade and foreign exchange system, 6) competition policy, 7) banking reform and interest rate liberalisation, 8) securities markets and non-bank financial institutions and 9) infrastructure that includes electric power, railways, telecommunication, roads, water and waste water. The measurement scale for these indicators ranges from 1 to $4+$, where 1 represents little or no change from a rigid centrally planned economy while $4+$ represents the standards of an industrialized market economy. The indicators mentioned above can be considered a broad measure of wider economic 'institutional' progress as they include both elements of institutional environment and institutional arrangements under the NIE (North, 1971; Williamson, 1971).

In order to suit the objective of the paper and given the differing importance of various aspects of institutional development for an economy in transition; we construct the following institutional indicators from the set of nine available indicators as described below: 
- Economic Governance Reform Index (EGRI): composite index based on unweighted average of large scale privatization and corporate governance and enterprise restructuring

- Overall Market Liberalization Index (OMLI): composite index based on unweighted average price liberalization, competition policy and trade and foreign exchange system

- Other Infrastructure Reform Index (OIRI): composite index based on unweighted average of reform scores in roads, water and waste water and telecommunication

- Financial Reform Index (FRI): composite index based on un-weighted average of banking reform and interest rate liberalization and securities markets and non-bank financial institutions

- Power Sector Reform Index (PRI): power sector reform index alone

Small scale privatization and reform in railways have been ignored in our study as we believe small scale privatization is en-route to large scale privatization and thus avoid double-counting. The size and nature of the industry may mean that power sector is more prone to large scale privatization than small scale privatization. Railways have been ignored because of many missing observations ${ }^{14}$. Since our aim is to analyze the relationship between the institutional framework on macroeconomic and power sector outcomes (economic, technical and environmental), the following classification of outcome variables was made as described below ${ }^{15}$ :

- Economic impacts: includes per capita GDP (PGDP) and per capita installed capacity (PINSTC) and per capita renewable installed capacity (PRINSTC)

- Technical impacts: includes operational aspects namely per capita transmission and distribution losses (PTDL) and per capita electricity production (PEPDN) and per capita renewable production (PREPDN)

- Environmental impacts: includes carbon emissions intensity (CEI) and energy intensity (EI)

GDP and installed capacity are classified under economic impacts as the former measures the economic well-being of an individual (i.e. per capita income) while the latter measure is reflective of the capital investments devoted to electricity generation and expansion capacity. We would have ideally liked to study the impact

\footnotetext{
${ }^{14}$ EBRD (2001) in its transition report has also constructed a measure for institutional development which is the composite index of unweighted average of transition indicators for 2001 comprising largescale privatization, governance and enterprise reform, competition policy, infrastructure and finance. But, our construct of the institutional index will allow us to comment on the relative importance of different institutional components.

${ }^{15}$ It is to be understood that the above classification is not typically very distinct from one another as the classifications can be highly correlated and hence debatable. But, for the sake of preciseness and simplicity, we assume that the above classification holds true.
} 
of reforms on private investments in the electricity sector but the lack of a comprehensive dataset on power sector private investments proved to be a major constraint. Transmission and distribution (T\&D) losses is largely due to technical constraints in the grids and correlated to capital investments in the T\&D infrastructures. Likewise, electricity production can significantly depend upon the available technology in place and also dependent on the available installed capacity too. 'Per capita' approximation is used for all the above measures to homogenize the effect of increasing population across all outcomes. Likewise, carbon intensity is a direct measure of the amount of carbon emissions released in relation to GDP while energy intensity is a measure of energy efficiency bearing enormous consequences to the environment. As mentioned, these outcomes are to be studied accounting for electricity consumption (demand).

The variables PGDP, PINSTC, PEPDN, PTDL, CEI, El as well as the control variable i.e. electricity demand, were logarithmic transformed. Electricity prices (both household and industrial) is not included in our analysis for two reasons: a) the neoclassical economic theory vastly relied on prices for the market to deliver its 'goods' so this paper departs from neo-classical theory by placing tremendous emphasis on institutions and b) the lack of a reliable comprehensive data.

The time frame considered in this study ranges from 1990 to 2008 . The year 1990 was the start of the massive transition process among the TECs while a comprehensive data beyond 2008 was not available in the EBRD dataset. Annual data is available for only 27 diverse transition countries where EBRD has been actively involved. Some of these countries have already obtained a membership at the EU while some are in the process of being an EU member and have the potential for joining EU. Table 2 shows the status of the countries included in the sample in terms of EU accession and that 15 out of 27 countries included in our sample are associated with the EU. Turkey and Montenegro ${ }^{16}$ are excluded from our sample due to data unavailability on the predictor and criterion variables respectively. Table 3 lists and describes the variables.

\begin{tabular}{|l|l|l|}
\hline \multicolumn{1}{|c|}{ EU members } & \multicolumn{1}{|c|}{ EU Candidate members } & \multicolumn{1}{|c|}{$\begin{array}{c}\text { Potential Candidate } \\
\text { members }\end{array}$} \\
\hline $\begin{array}{l}\text { 2004: Estonia, Hungary, } \\
\text { Latvia, Lithuania, Poland, } \\
\text { Slovakia, Slovenia }\end{array}$ & $\begin{array}{l}\text { Croatia, FYR Macedonia, } \\
\text { Turkey }\end{array}$ & $\begin{array}{l}\text { Albania, BIH, Montenegro, } \\
\text { Serbia }\end{array}$ \\
\hline
\end{tabular}

Table 2: EU associated countries in EBRD area of operation

Source: Own compilation

\footnotetext{
${ }^{16}$ Montenegro only became an independent state from 3 June 2006.
} 


\begin{tabular}{|c|c|c|c|c|}
\hline Type & Variables & Description & Units & Source \\
\hline \multirow{5}{*}{$\begin{array}{l}\text { Independent } \\
\text { Variables }\end{array}$} & PRI & Power reform index & $\begin{array}{l}\text { Scaled from } 1 \text { to } \\
4+\end{array}$ & EBRD \\
\hline & OIRI & $\begin{array}{l}\text { Other infrastructure } \\
\text { reform index }\end{array}$ & $\begin{array}{l}\text { Scaled from } 1 \text { to } \\
4+\end{array}$ & EBRD \\
\hline & FRI & $\begin{array}{l}\text { Financial reform } \\
\text { index }\end{array}$ & $\begin{array}{l}\text { Scaled from } 1 \text { to } \\
4+\end{array}$ & EBRD \\
\hline & EGRI & $\begin{array}{l}\text { Economic } \\
\text { Governance reform } \\
\text { index }\end{array}$ & $\begin{array}{l}\text { Scaled from } 1 \text { to } \\
4+\end{array}$ & EBRD \\
\hline & OMLI & $\begin{array}{l}\text { Overall market } \\
\text { liberalization index }\end{array}$ & $\begin{array}{l}\text { Scaled from } 1 \text { to } \\
4+\end{array}$ & EBRD \\
\hline Control variable & LNPECS & $\begin{array}{l}\text { Per capita } \\
\text { electricity } \\
\text { consumption }\end{array}$ & $\begin{array}{l}\text { Kilowatt hour } \\
\text { (KWh) }\end{array}$ & ClA World Factbook \\
\hline \multirow{8}{*}{$\begin{array}{l}\text { Dependent } \\
\text { variables }\end{array}$} & LNPGDP & $\begin{array}{l}\text { Per capita GDP or } \\
\text { per capita income }\end{array}$ & $\begin{array}{l}\text { Constant } 2000 \text { US } \\
\text { dollars }\end{array}$ & $\begin{array}{l}\text { World Development } \\
\text { Indicators (WDI) }\end{array}$ \\
\hline & LNPINSTC & $\begin{array}{l}\text { Per capita installed } \\
\text { capacity }\end{array}$ & KWh per person & EIA \\
\hline & LNPRINSTC & $\begin{array}{l}\text { Per capita } \\
\text { renewable installed } \\
\text { capacity }\end{array}$ & KW per person & EIA \\
\hline & LNPEPDN & $\begin{array}{l}\text { Per capita } \\
\text { electricity } \\
\text { production }\end{array}$ & KWh per person & EIA \\
\hline & LNPREPDN & $\begin{array}{l}\text { Per capita } \\
\text { renewable } \\
\text { electricity } \\
\text { production }\end{array}$ & KWh per person & EIA \\
\hline & LNPTDLS & $\begin{array}{l}\text { Per capital } \\
\text { transmission and } \\
\text { distribution losses }\end{array}$ & KWh & WDI \\
\hline & LCE & $\begin{array}{l}\text { Total carbon } \\
\text { emissions/GDP }\end{array}$ & $\begin{array}{l}\text { Metric tons of } \\
\text { carbon dioxide } \\
\text { per Thousand } \\
\text { Year } 2005 \text { US } \\
\text { Dollars (market } \\
\text { exchange rates) }\end{array}$ & EIA \\
\hline & LEI & $\begin{array}{l}\text { Total energy } \\
\text { consumption/GDP }\end{array}$ & $\begin{array}{l}\text { Btu per Year } 2005 \\
\text { US Dollars } \\
\text { (market exchange } \\
\text { rates) }\end{array}$ & EIA \\
\hline $\begin{array}{l}\text { Conversion } \\
\text { variable }\end{array}$ & Population & $\begin{array}{l}\text { Includes all } \\
\text { residents regardless } \\
\text { of legal status or } \\
\text { citizenship }\end{array}$ & Total number & WDI \\
\hline
\end{tabular}

Table 3: List and Description of variables

Source: Own Compilation 
Our dataset thus is an unbalanced panel comprising 27 cross-sections (N) with short time series $(T)$ of 19 years observed from period 1990-2008. The cross-sections represent a diverse set of countries with its own economic, political, cultural, etc. system and history allowing every possibility for individual country-specific characteristics to influence the behavior of each. The panel data econometric methods consisting fixed effects (FE) and random effects (RE) estimators are widely used to account for unobserved heterogeneity in econometric literature. The FE and RE estimators differ in the way the assumptions are made about the unobserved heterogeneity. The RE estimator assumes that the composite error term (i.e. also containing the individual effect) must be uncorrelated with the explanatory variable and thus be treated as if they were a part of the error term. On the other hand FE estimator uses a dummy for every individual country ${ }^{17}$ and thus overtly takes the unobserved heterogeneity into account. Hence, the FE estimator is also popularly known as the Least Squares Dummy Variable (LSDV) estimator. So, the FE estimator is a special case of the RE estimator in itself. The RE estimator where applicable (i.e. provided the assumptions ${ }^{18}$ on the error term are met) is more efficient meaning that it has the lowest variance amongst unbiased estimators. Accordingly, the FE estimator is always consistent implying that the estimator converges in probability to the true value of the parameter. A Hausman Test can be used to make an appropriate choice upon applying RE and FE.

However, we have used the FE estimator in this paper because unobserved heterogeneity such as culture, legal origin, geographical location, history etc. that are fixed over time are likely to be correlated with the wider economic reforms taking place in the economy. Under this case, the fundamental assumption of RE model is violated and not useful. The data used in this study also does not represent a random sample as ' $N$ ' is limited but represents a finite sample allowing the use of $\mathrm{FE}$ estimator. A static FE model can be specified as $y_{i t}=\beta_{0}+X_{i t} \beta+\alpha_{i}+u_{i t}$ which can be estimated using commands ' $x$ treg' or 'xtregar' for AR (1) estimates in STATA.

But, it is necessary to understand that relationship between the institutional framework and energy sector outcomes is a complex one as the creation of a suitable institutional environment does not instantaneously lead to improved outcomes. The behavior of dependent variables can depend upon the past values of itself along with a set of independent and control variables (Bruno, 2005). Thus a

\footnotetext{
${ }^{17}$ An alternative way to understand FE estimation would be by assigning country specific dummy while performing a pooled Ordinary Least Squares (OLS) regression. On the other hand, a FE estimator takes into account the temporal (i.e. within) variation of the relevant variables and hence produce appropriate results when applied to variables that considerably vary over time.

${ }^{18}$ The RE estimator is applicable on the assumption that the individual unobserved heterogeneity must be uncorrelated with the regressors (explanatory variables).
} 
dynamic specification of the panel model can be specified as $y_{i t}=\Omega y_{i t-1}+X_{i t} \beta+\alpha_{i}+$ $u_{i t}$ where ' $\Omega$ ' is the coefficient of the lagged value of the dependent variable while ' $X_{i t} \beta$ ' represents the matrix of explanatory variables and coefficients. Hence, we use a dynamic LSDV (i.e. FE) model in this study.

But, it is well established in econometric literature that a dynamic LSDV model with a lagged dependent variable engenders biased estimates when ' $T$ ' is small as in our case (for e.g. see Roodman, 2006). Thus, Kiviet (1995) devised a bias-corrected LSDV estimator applicable only for balanced panels which is generally understood to have the lowest Root Mean Square Error(RMSE) for panels of all sizes (Bun and Kiviet, 2003). However, a version of bias-corrected LSDV estimate (LSDVC) has been developed by Bruno (2005) that can be applied under two fundamental assumptions: a) it has a strictly exogenous selection rule and b) the error term ' $u_{i t}$ ' is classified as 'an unobserved white noise disturbance'. Using 'xtlsdvc'command in STATA, the estimator first produces uncorrected LSDV estimates which then approximates the sample bias of the estimator using Kiviet's higher order asymptotic expansion techniques (Bruno, 2005). The approximation terms are of no direct use for estimation as they are all evaluated at the unobserved true parameter values. So, the true parameter values are replaced by estimates from some consistent estimator to make them work (Bruno, 2005). The preferred estimator is then plugged into the bias approximations formulae while the resulting bias approximation estimates $\beta_{\mathrm{i} \text { hat }}$ is subtracted to derive the corrected LSDV estimator as LSDVC $C_{i}=L S D V-\beta_{i}$ hat where $i=1$ in STATA by default that indicates the accuracy of the bias approximation. The consistent estimator to be chosen to initialize the bias corrections could vary between the Anderson-Hsiao (AH), Arellano-Bond (AB) and Blundell-Bond (BB) estimators.

An alternative to dynamic LSDV panel estimates would be to use other consistent Instrumental Variable (IV) and Generalized Methods of Moments (GMM) estimators as widely proposed in econometrics (Roodman, 2006). But, the relative performance evaluation of LSDVC in comparison to LSDV, Anderson-Hsiao, Arellano-Bond and Blundell-Bond estimators by Bruno (2005) for unbalanced panels with small $N$ concludes that the STATA computed LSDVC version outperform all other estimators in terms of RMSE and bias. We thus use the LSDVC model to test the formulated hypotheses under section three that involved dynamic relationship and accordingly report the results for all the estimators used to initialize the bias corrections (Anderson-Hsiao, Arellano-Bond and Blundell-Bond). The use of indexes based on individual components score as regressors while considering electricity demand in an economy as given largely confirms to the exogenous selection rule as required. The standard test statistics along with the Arellano-Bond test for first and second order autocorrelation is reported. Under the null of no autocorrelation, the presence of 
second order autocorrelation would imply that the estimates are inconsistent. In addition, the estimates of the Sargan test of overidentifying restrictions reported by the Blundell Bond estimator should test significantly from zero to reject the null that overidentifying restrictions are valid. As an example on the empirical application of the LSDVC estimator; Sen and Jamasb (2010) have performed an econometric analysis of the determinants and impacts of electricity reform in India.

But, the model used in this paper is quite different from them as we also use the interaction terms to assess the impacts of wider economic reforms and power sector reforms on the energy and macroeconomic outcomes in the transition economies. We would have also liked to incorporate time-dummies in our model to capture any event specific outcomes (for e.g. Asian financial crisis, EU joining etc.) but doing so will severely limit the degrees of freedom in our analysis given the limited dataset. Hence, we avoided using time dummies. Following Sen and Jamasb (2010), Zhang et al. $(2008)^{19}$ for electricity sector reform, the first model (model I) to be estimated to test our hypotheses is:

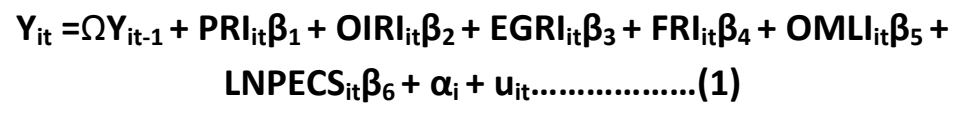

All dependent and independent variables except indexes have been logarithmic transformed. We use per capita electricity consumption in our analysis as a control variable as discussed above. As already mentioned the motives to reform the power sector in the TECs were primarily external so reforms in external sector alone and in relation to the power sector could have affected the macroeconomic and power sector outcomes. In order to study so, it is necessary to introduce an interaction term between the power sector reforms with wider economic institutional reforms as specified in our second model (model II) below ${ }^{20}$ :

$$
\begin{aligned}
& Y_{i t}=\Omega Y_{i t-1}+P R I_{i t} \beta_{1}+O I R I_{i t} \beta_{2}+E G R I_{i t} \beta_{3}+F R I_{i t} \beta_{4}+O M L I_{i t} \beta_{5}+L N P E C S_{i t} \beta_{6}+
\end{aligned}
$$

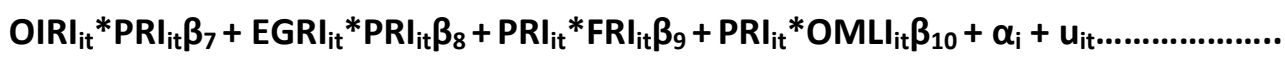

Table 4 reports the descriptive variables used in our study. It can be well understood from the table that the power sector in the TECs has been reformed the least in relation to the standards of an industrialized market economy. The countries on average seem to have fairly reformed the overall market liberalization of the

\footnotetext{
${ }^{19}$ Zhang et al. (2008) have also used interactions terms in panel data regressions but they have used static fixed effects on a large sample while we use dynamic fixed effects for a small sample with bias correction.

${ }^{20}$ Note that questions can be raised here regarding other possible interactions among regressors. However, given our research objective as clearly stated in different sections of the paper, we have only considered the interaction the power sector reform with other institutional reforms.
} 
economy. This might have been achieved by opening the market (i.e. open economy) to significantly benefit from the increasing regional trading and integration. However, disaggregating the diverse set of countries into different groups based on their common characteristics (as in figure ten) would allow studying the relative institutional reform progress more precisely than solely relying on the overall average. The variables also proved to be stationary over the time period considered in this study and thereby avoiding the pitfalls of spurious regressions. Table $F$ in appendix I reports the results from unit root tests based on the 'ipshin' module in STATA as suggested by Im et al. (1995). The results confirm that the variables are integrated of order one I(1) at $1 \%$ level of significance and thus stationary in their first differences.

\begin{tabular}{|c|c|c|c|c|c|}
\hline Variable & Mean & $\begin{array}{c}\text { Standard } \\
\text { Deviation }\end{array}$ & Minimum & Maximum & $\begin{array}{c}\text { No. of } \\
\text { observations }\end{array}$ \\
\hline LNPRINSTC & -2.211 & 2.061 & -8.526 & 0 & 490 \\
\hline LNPREPDN & 5.407 & 2.315 & -5.195 & 8.013 & 472 \\
\hline LNPGDP & 7.360 & 0.992 & 4.805 & 9.532 & 509 \\
\hline LNPINSTC & -0.141 & 0.474 & -2.282 & 0.809 & 490 \\
\hline LNPEPDN & -5.801 & 0.513 & -7.108 & -4.502 & 513 \\
\hline LNPTDLS & -7.782 & 0.431 & -8.977 & -6.663 & 513 \\
\hline PRI & 1.994 & 0.814 & 1 & 3.67 & 513 \\
\hline OIRI & 2.013 & 0.796 & 1 & 3.92 & 513 \\
\hline EGRI & 2.236 & 0.855 & 1 & 3.84 & 513 \\
\hline OMLI & 2.949 & 0.888 & 1 & 4.22 & 513 \\
\hline FRI & 2.065 & 0.810 & 1 & 4 & 513 \\
\hline CEI & 2.560 & 2.139 & 0.368 & 11.523 & 467 \\
\hline EI & 46570 & 41249.45 & 7792.694 & 201994.7 & 466 \\
\hline LNPECS & 7.866 & 0.515 & 5.979 & 8.873 & 513 \\
\hline
\end{tabular}

Table 4: Table E: Descriptive statistics for the variables

Figure 10 shows that liberalizing the economy as a whole (i.e. opening up trade, establish proper competition policies and price liberalization in the economy) has been on high agenda of reforms across all countries in transition. However, overall price liberalization is the economy has not necessarily implied the price liberalization in the power sector as all groups of countries considered are still a distant apart from achieving a cost-reflective electricity pricing ${ }^{21}$. The figure also depicts some degree of institutional convergence among PRI, OIRI, EGRI and FRI variables across all CEB, SEE and CIS member states. The CEB countries which includes 7 out of 9 EU members

\footnotetext{
${ }^{21}$ According to EBRD, a PRI of 4 would indicate that the countries have engaged in full cost reflective pricing of utilities services.
} 
included in our sample seem to have experienced a stagnation of institutional reforms including the power sector reforms though the financial sector reforms is following an upward trend. The SEE countries however exhibit an upward reform trend in other institutional reforms expect for the power sector. The CIS countries on the other hand depict a mixed scenario. The steep upward general trend in PRI among $\mathrm{CIS}$ countries reveals that these countries have a lot of catching up to do in relation to its counterparts in reforming the power sector. The overall market liberalization process though seems to have flattened out post 2004 while reforms in economic governance, other infrastructures and financial sector are gaining pace.

A detailed analysis of EU members in particular gives a much more apparent outlook on the power sector reforms. Power sector reforms seem to have sped up after financial crisis till the EU accession in 2004 (Estonia, Hungary, Latvia, Lithuania, Poland, Slovakia and Slovenia) before a brief moment of respite. The reforms process again gained pace probably with Bulgaria and Romania in the process of joining $\mathrm{EU}^{22}$. However, after 2005 power sector reforms appears to have stagnated among the EU members while other institutional reforms considered in our study looks slowly showing an upward trend. Likewise, the power sector reform gained pace in the EU (potential) candidates (Albania, BIH, Montenegro, Serbia, Croatia, FYR Macedonia) after 2000 but stagnation looms post 2005. Other institutional reforms in the EU candidate countries are showing an upward trend. Hence the motives of joining EU indeed acted as incentives to speed up the power sector reforms across these countries.

A further analysis of the oil and gas rich countries included in our sample (namely Azerbaijan, Kazakhstan, Russia and Turkmenistan) shows that power sector reform gained pace after 2000 with a reversal around 2004 and thus stagnation after 2005. While reforms in other infrastructures (i.e. other utilities) is speeding up, reforms in overall market liberalization, economic governance and financial sector reform seems to have stalled. Although a detailed econometric analysis of these groups as per the above classification is not viable under a small data set, the next section presents and discusses the econometric results testing the formulated hypotheses under section two ${ }^{23}$ using Model I and Model II.

\footnotetext{
${ }^{22}$ They eventually joined in 2007.

${ }^{23}$ Table E in Appendix I reports the correlation results for the independent variables used in this study.
} 


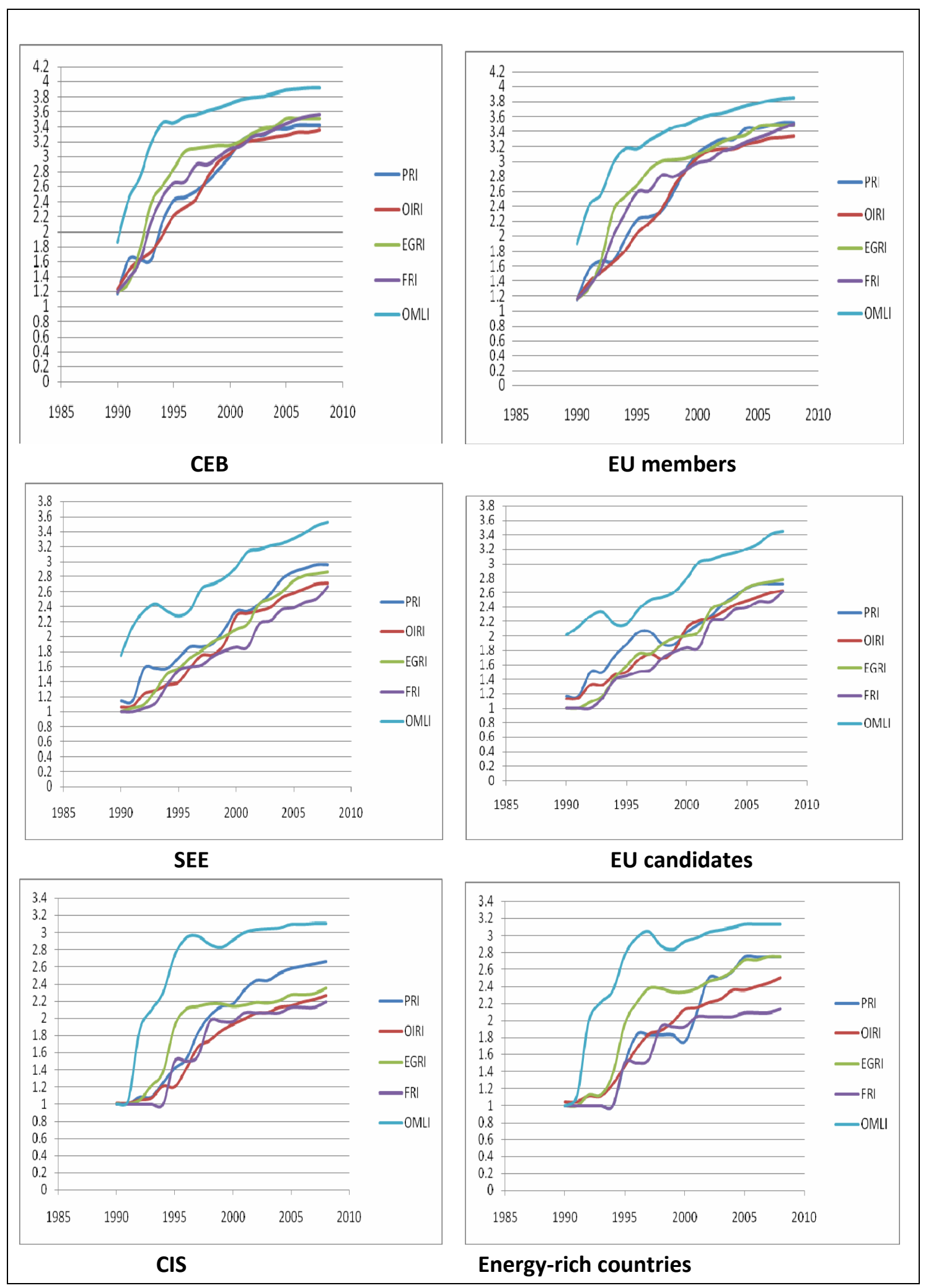

Figure 10: Graphical analysis of economy-wide reform progress Source: Own compilation based on EBRD 


\section{Results}

This section presents and discusses the econometric results from the hypotheses testing based on model (I) and model (II) ${ }^{24}$ using the 'LSDVC' technique as described in section 3. The results are classified under the economic, operational and environmental impacts of power sector and other institutional reforms. Model (I) explains the 'on its own' impact of reforms alone over-time while Model (II) explains the outcomes also accounting for different interactions between the power sector reforms and other institutional reforms. In both models, per capita electricity consumption was used as a control variable.

a) The Economic impacts of reform: Per capita GDP, per capita installed capacity and per capita renewable installed capacity were considered as the outcomes variables to assess the economic impacts of power sector reforms and wider institutional reform in the TECs. Test results of hypotheses 1, 2 and 2.1 are discussed below.

i) Hypothesis 1: The results in table 5 shows that the lagged value of GDP is significant implying that last year's GDP had a significant effect on these years GDP across the transition countries. Power sector reform on its own, does not bring about a change in per capita GDP. However, accounting for different interactions between power sector reforms and other institutional reforms; the power sector reforms significantly affected the GDP. Interestingly, electricity reforms when considered along with overall market liberalization reforms had a significant negative effect on per capita GDP. This could be explained on the grounds that competition policy in the transition countries is much less advanced than the reforms in the power sector when competition policy is an essential part of any electricity reform as market oriented reforms renders greater responsibilities to competition authorities to implement reforms (Pollitt, 2009). Such results portray the complexities involving the power sector reforms and thus the need to consider wider institutional aspects surrounding power sector reforms. Likewise, reforms in other infrastructures (telecommunication, water and roads), economic governance (large scale privatization and enterprise restructuring), and overall market liberalization (opening up trade, liberalizing prices under certain competition policy) all produced a significant impact on per capita GDP. Thus, in some ways it can be inferred that regional integration and increasing cross-border trading of goods and services (including the energy trade) proved favorable in terms of boosting national GDP. But, it is not clear from our results upon which aspect of institutional reform in particular was the most important in influencing the national GDP and which countries gained

\footnotetext{
${ }^{24}$ The interaction term in this study has been derived by multiplying the indexes under consideration. However, an alternative approach of contructing the interation term by considering the average deviation from the mean also performed although the results were not significantly different. Thus, we applied the former one in the paper.
} 
or lost. Nonetheless, countries that had the macroeconomic motives to reform their power sector benefited when power sector reforms took place in conjunction with institutional reforms as suggested by our results.

Per capita electricity consumption also has a significant effect on per capita GDP in the transition countries confirming that these countries are energy-intensive. The traces of decade's long experience of the economy overtly riding on cheap and state subsidized energy in the transition countries seems to be still present as confirmed by the overall results ${ }^{25}$.

\begin{tabular}{|c|c|c|c|c|c|c|}
\hline \multicolumn{7}{|c|}{ Impact of reforms on per capita GDP } \\
\hline \multirow[t]{2}{*}{ Variables } & \multicolumn{2}{|c|}{ Anderson-Hsiao } & \multicolumn{2}{|c|}{ Arellano-Bond } & \multicolumn{2}{|c|}{ Blundell-Bond } \\
\hline & Model I & Model II & Model I & Model II & Model I & Model II \\
\hline L.LNPGDP & $\begin{array}{l}0.896 * * * \\
(0.038)\end{array}$ & $\begin{array}{l}0.893 * * * \\
(0.002)\end{array}$ & $\begin{array}{l}.935 * * * \\
(0.030)\end{array}$ & $\begin{array}{l}0.967 * * * \\
(0.041)\end{array}$ & $\begin{array}{l}0.975 * * * \\
(0.043)\end{array}$ & $\begin{array}{l}0.942 * * * \\
(0.031)\end{array}$ \\
\hline PRI & $\begin{array}{l}0.003 \\
(0.005)\end{array}$ & $\begin{array}{l}0.125^{* * *} \\
(0.021)\end{array}$ & $\begin{array}{l}0.005 \\
(0.004)\end{array}$ & $\begin{array}{l}0.060 * * * \\
(0.020)\end{array}$ & $\begin{array}{l}0.003 \\
(0.008)\end{array}$ & $\begin{array}{l}0.099 * * * \\
(0.027)\end{array}$ \\
\hline OIRI & $\begin{array}{l}0.030 * * * \\
(0.007)\end{array}$ & $\begin{array}{l}0.049 * * \\
(0.021)\end{array}$ & $\begin{array}{l}0.009 \\
(0.007)\end{array}$ & $\begin{array}{l}0.044^{* *} \\
(0.018)\end{array}$ & $\begin{array}{l}0.006 \\
(0.010)\end{array}$ & $\begin{array}{l}0.057^{*} \\
(0.031)\end{array}$ \\
\hline EGRI & $\begin{array}{l}0.068 * * * \\
(0.007)\end{array}$ & $\begin{array}{l}0.051^{*} \\
(0.027)\end{array}$ & $\begin{array}{l}0.012^{*} \\
(0.006)\end{array}$ & \begin{tabular}{|l|}
0.009 \\
$(0.023)$
\end{tabular} & $\begin{array}{l}0.016^{*} \\
(0.008)\end{array}$ & $\begin{array}{l}0.019 \\
(0.031)\end{array}$ \\
\hline OMLI & $\begin{array}{l}0.063 * * * \\
(0.007)\end{array}$ & $\begin{array}{l}0.015 \\
(0.019)\end{array}$ & $\begin{array}{l}.015^{* *} \\
(0.006)\end{array}$ & \begin{tabular}{|l|}
0.016 \\
$(0.017)$
\end{tabular} & $\begin{array}{l}0.016 \\
(0.008)\end{array}$ & $\begin{array}{l}0.024 \\
(0.021)\end{array}$ \\
\hline FRI & $\begin{array}{l}0.009 \\
(0.298)\end{array}$ & $\begin{array}{l}0.020 \\
(0.031)\end{array}$ & $\begin{array}{l}0.007 \\
(0.274)\end{array}$ & \begin{tabular}{|l|}
0.019 \\
$(0.027)$
\end{tabular} & $\begin{array}{l}0.005 \\
(0.010)\end{array}$ & $\begin{array}{l}0.016 \\
(0.031)\end{array}$ \\
\hline LNPECS & $\begin{array}{l}0.171 * * * \\
(0.011)\end{array}$ & $\begin{array}{l}0.073^{* * *} \\
(0.011)\end{array}$ & $\begin{array}{l}0.004 \\
(0.011)\end{array}$ & \begin{tabular}{|l|}
0.006 \\
$(0.012)$ \\
\end{tabular} & $\begin{array}{l}0.035^{* *} \\
(0.004)\end{array}$ & $\begin{array}{l}0.042 * * \\
(0.025)\end{array}$ \\
\hline $\mathrm{PRI} * \mathrm{OIRI}$ & & $\begin{array}{l}-0.025 \\
(0.010)\end{array}$ & & \begin{tabular}{|l|}
-0.015 \\
$(0.009)$
\end{tabular} & & $\begin{array}{l}-0.022 \\
(0.015)\end{array}$ \\
\hline PRI*EGRI & & \begin{tabular}{|l|}
-0.002 \\
$(0.013)$ \\
\end{tabular} & & \begin{tabular}{|l|}
0.001 \\
$(0.011)$ \\
\end{tabular} & & $\begin{array}{l}-0.006 \\
(0.015) \\
\end{array}$ \\
\hline $\mathrm{PRI}^{*} \mathrm{OMLI}$ & & $\begin{array}{l}-.051 * * * \\
(0.117)\end{array}$ & & \begin{tabular}{|l|}
-0.008 \\
$(0.011)$
\end{tabular} & & $\begin{array}{l}-0.017 \\
(0.017)\end{array}$ \\
\hline PRI*FRI & & $\begin{array}{l}-0.008 \\
(0.015)\end{array}$ & & \begin{tabular}{|l|}
-0.001 \\
$(0.013)$
\end{tabular} & & $\begin{array}{l}-0.042 \\
(0.124)\end{array}$ \\
\hline
\end{tabular}

\footnotetext{
${ }^{25}$ Though not shown in the paper, we also perform an OLS and FE (i.e. LSDV) estimations and compare the results to determine the nature of bias for each hypothesis. In all cases, bias was observed as OLS and FE does not take endogeneity into account.

${ }^{26}$ The bootstrapped standard errors are reported in brackets. We have performed a third order bias correction while the number of bootstrapping repetitions has been confined to 50 depending on the number of observations.
} 
ii) Hypothesis 2: Per capita generation installed capacity remained fairly inelastic to power sector reforms and per capita electricity consumption in the transition countries. The reason could be due to the excess generation capacity of the past implying that there is no urgency to invest in capacity expansion. The one-lagged coefficient is also significant indicating that last year's capacity is an important indicator for the current year's capacity. All other institutional coefficients except EGRI (with and without the interaction terms) are insignificant in explaining any changes in per capita installed capacity. However, the economic governance index (large scale privatization and corporate governance with enterprise restructuring) is negatively significant to per capita installed capacity. The result reveals the rampant power sector privatization as a 'shock therapy' that took place in the yesteryears with the sole motive of raising revenue. In most cases, privatization occurred without any appropriate framework for privatization itself (e.g. appropriate legal structure, a proper regulatory and completion framework etc.).

\begin{tabular}{|c|c|c|c|c|c|c|}
\hline \multicolumn{7}{|c|}{ Impact of reforms on per capita installed capacity } \\
\hline \multirow[t]{2}{*}{ Variables } & \multicolumn{2}{|c|}{ Anderson-Hsiao } & \multicolumn{2}{|c|}{ Arellano-Bond } & \multicolumn{2}{|c|}{ Blundell-Bond } \\
\hline & Model I & Model II & Model I & Model II & Model I & Model II \\
\hline L.LNPINSTC & $\begin{array}{c}0.918^{* * *} \\
(0.154)\end{array}$ & $\begin{array}{c}0.911^{* * *} \\
(0.148)\end{array}$ & $\begin{array}{c}0.924^{* * *} \\
(0.030)\end{array}$ & $\begin{array}{c}0.916^{* * *} \\
(0.033)\end{array}$ & $\begin{array}{c}1.176^{* * *} \\
(0.016)\end{array}$ & $\begin{array}{c}1.16^{* * *} \\
(0.018)\end{array}$ \\
\hline PRI & $\begin{array}{c}0.006 \\
(0.018)\end{array}$ & $\begin{array}{c}0.028 \\
(0.074)\end{array}$ & $\begin{array}{c}0.005 \\
(0.010)\end{array}$ & $\begin{array}{c}0.015 \\
(0.037)\end{array}$ & $\begin{array}{c}0.023 \\
(0.015)\end{array}$ & $\begin{array}{l}-0.018 \\
(0.053)\end{array}$ \\
\hline OIRI & $\begin{array}{c}0.007 \\
(0.023)\end{array}$ & $\begin{array}{c}0.030 \\
(0.060)\end{array}$ & $\begin{array}{c}0.007 \\
(0.016)\end{array}$ & $\begin{array}{c}0.035 \\
(0.042)\end{array}$ & $\begin{array}{l}-0.001 \\
(0.023)\end{array}$ & $\begin{array}{c}0.083 . \\
(0.044)\end{array}$ \\
\hline EGRI & $\begin{array}{c}-0.032 \\
(0.020)\end{array}$ & $\begin{array}{l}-0.091^{*} \\
(0.054)\end{array}$ & $\begin{array}{l}-.034^{* *} \\
(0.013)\end{array}$ & $\begin{array}{l}-.085 * * \\
(0.037)\end{array}$ & $\begin{array}{c}-0.056^{* * *} \\
(0.014)\end{array}$ & $\begin{array}{l}-0.086 \\
(0.047)\end{array}$ \\
\hline OMLI & $\begin{array}{c}0.009 \\
(0.021)\end{array}$ & $\begin{array}{c}0.045 \\
(0.057)\end{array}$ & $\begin{array}{c}0.009 \\
(0.013)\end{array}$ & $\begin{array}{c}0.039 \\
(0.034)\end{array}$ & $\begin{array}{c}0.016 \\
(0.017)\end{array}$ & $\begin{array}{l}-0.003 \\
(0.044)\end{array}$ \\
\hline FRI & $\begin{array}{c}0.015 \\
(0.019)\end{array}$ & $\begin{array}{c}0.014 \\
(0.076)\end{array}$ & $\begin{array}{c}0.018 \\
(0.016)\end{array}$ & $\begin{array}{c}0.003 \\
(0.047)\end{array}$ & $\begin{array}{c}0.022 \\
(0.290)\end{array}$ & $\begin{array}{l}-0.024 \\
(0.067)\end{array}$ \\
\hline LNPECS & $\begin{array}{c}0.018 \\
(0.037)\end{array}$ & $\begin{array}{c}0.073 \\
(0.011)\end{array}$ & $\begin{array}{c}0.018 \\
(0.018)\end{array}$ & $\begin{array}{c}0.021 \\
(0.021)\end{array}$ & $\begin{array}{l}-0.018 \\
(0.019)\end{array}$ & $\begin{array}{l}-0.018 \\
(0.020)\end{array}$ \\
\hline $\mathrm{PRI} * \mathrm{OIRI}$ & & $\begin{array}{l}-0.017 \\
(0.027)\end{array}$ & & $\begin{array}{l}-0.019 \\
(0.029)\end{array}$ & & $\begin{array}{l}-0.047 \\
(0.022)\end{array}$ \\
\hline PRI*EGRI & & $\begin{array}{l}-0.036 \\
(0.029)\end{array}$ & & $\begin{array}{c}0.031 \\
(0.019)\end{array}$ & & $\begin{array}{l}-0.017 \\
(0.024)\end{array}$ \\
\hline PRI*OMLI & & $\begin{array}{c}-.021 \\
(0.031)\end{array}$ & & $\begin{array}{l}-0.016 \\
(0.018)\end{array}$ & & $\begin{array}{c}-0.017 \\
(0.017)\end{array}$ \\
\hline PRI*FRI & & $\begin{array}{l}-0.002 \\
(0.041)\end{array}$ & & $\begin{array}{l}-0.005 \\
(0.023)\end{array}$ & & $\begin{array}{c}0.022 \\
(0.029)\end{array}$ \\
\hline
\end{tabular}


While such privatization indeed raised money for the government, the receipts from privatization was not primarily necessarily channelized in adding more generation capacity while some privately owned ones might have shut down to low power prices and inability to recover the cost. Stiglitz (1999) explains the so-called 'the velvet globe of privatization' where privatization occurred backdoors with ill-motives resulting in mass corruption. Thus, mass privatization of the power sector with a motive to add generation capacity has defied the logics in the transition countries as per our results (see table 6 below).

iii) Hypothesis 2.1: Following earlier results and explanation, the lagged value of per capita renewable installed capacity is significant while all other variables including the power sector reforms but excluding the financial sector reforms seems to be insignificant in bringing about changes in per capital renewable installed capacity. Table 7 shows that financial sector reforms on its own are crucial in generating additional renewable capacity.

\begin{tabular}{|c|c|c|c|c|c|c|}
\hline \multicolumn{7}{|c|}{ Impact of reforms on renewable per capita installed capacity } \\
\hline \multirow[t]{2}{*}{ Variables } & \multicolumn{2}{|c|}{ Anderson-Hsiao } & \multicolumn{2}{|c|}{ Arellano-Bond } & \multicolumn{2}{|c|}{ Blundell-Bond } \\
\hline & Model I & Model II & Model I & Model II & Model I & Model II \\
\hline L.LNRPINSTC & $\begin{array}{c}1.145^{* * *} \\
(0.024)\end{array}$ & $\begin{array}{c}1.018^{* * *} \\
(0.043)\end{array}$ & $\begin{array}{c}1.076^{* * *} \\
(0.016)\end{array}$ & $\begin{array}{c}1.078^{* * *} \\
(0.018)\end{array}$ & $\begin{array}{c}1.079 * * * \\
(0.011)\end{array}$ & $\begin{array}{c}1.078^{* * *} \\
(0.012)\end{array}$ \\
\hline PRI & $\begin{array}{c}-0.022 \\
(0.023)\end{array}$ & $\begin{array}{l}-0.121 \\
(0.093)\end{array}$ & $\begin{array}{l}-0.008 \\
(0.021)\end{array}$ & $\begin{array}{l}-0.055 \\
(0.069)\end{array}$ & $\begin{array}{c}-0.008 \\
(0.018)\end{array}$ & $\begin{array}{l}-0.062 \\
(0.059)\end{array}$ \\
\hline OIRI & $\begin{array}{c}0.010 \\
(0.033)\end{array}$ & $\begin{array}{l}-0.013 \\
(0.087)\end{array}$ & $\begin{array}{l}-0.004 \\
(0.030)\end{array}$ & $\begin{array}{l}-0.059 \\
(0.070)\end{array}$ & $\begin{array}{l}-0.001 \\
(0.027)\end{array}$ & $\begin{array}{l}-0.063 \\
(0.063)\end{array}$ \\
\hline EGRI & $\begin{array}{l}-0.017 \\
(0.023)\end{array}$ & $\begin{array}{l}-0.067 \\
(0.079)\end{array}$ & $\begin{array}{l}-0.027 \\
(0.022)\end{array}$ & $\begin{array}{l}-0.042 \\
(0.065)\end{array}$ & $\begin{array}{l}-0.026 \\
(0.021)\end{array}$ & $\begin{array}{l}-0.047 \\
(0.060)\end{array}$ \\
\hline OMLI & $\begin{array}{c}0.001 \\
(0.028)\end{array}$ & $\begin{array}{l}-0.029 \\
(0.067)\end{array}$ & $\begin{array}{l}-0.003 \\
(0.025)\end{array}$ & $\begin{array}{c}0.004 \\
(0.059)\end{array}$ & $\begin{array}{l}-0.004 \\
(0.022)\end{array}$ & $\begin{array}{l}-0.004 \\
(0.054)\end{array}$ \\
\hline FRI & $\begin{array}{l}0.034^{*} \\
(0.030)\end{array}$ & $\begin{array}{c}0.087 \\
(0.101)\end{array}$ & $\begin{array}{l}0.057^{*} \\
(0.030)\end{array}$ & $\begin{array}{c}0.076 \\
(0.082)\end{array}$ & $\begin{array}{c}0.055^{* *} \\
(0.026)\end{array}$ & $\begin{array}{c}0.093 \\
(0.075)\end{array}$ \\
\hline LNPECS & $\begin{array}{l}-0.044 \\
(0.044)\end{array}$ & $\begin{array}{l}-0.023 \\
(0.048)\end{array}$ & $\begin{array}{l}-0.028 \\
(0.034)\end{array}$ & $\begin{array}{l}-0.032 \\
(0.033)\end{array}$ & $\begin{array}{l}-0.022 \\
(0.031)\end{array}$ & $\begin{array}{c}0.022 \\
(0.030)\end{array}$ \\
\hline $\mathrm{PRI} * \mathrm{OIRI}$ & & $\begin{array}{l}-0.001 \\
(0.038)\end{array}$ & & $\begin{array}{c}0.022 \\
(0.032)\end{array}$ & & $\begin{array}{c}0.026 \\
(0.029)\end{array}$ \\
\hline PRI*EGRI & & $\begin{array}{l}-0.018 \\
(0.043)\end{array}$ & & $\begin{array}{c}0.008 \\
(0.034)\end{array}$ & & $\begin{array}{c}0.012 \\
(0.031)\end{array}$ \\
\hline $\mathrm{PRI} * \mathrm{OMLI}$ & & $\begin{array}{c}0.033 \\
(0.031)\end{array}$ & & $\begin{array}{c}0.004 \\
(0.032)\end{array}$ & & $\begin{array}{c}0.007 \\
(0.029)\end{array}$ \\
\hline PRI*FRI & & $\begin{array}{l}-0.015 \\
(0.049)\end{array}$ & & $\begin{array}{l}-0.015 \\
(0.406)\end{array}$ & & $\begin{array}{l}-0.024 \\
(0.036)\end{array}$ \\
\hline
\end{tabular}

$*, * *, * * *$ denotes significance at $10 \%, 5 \%$ and $1 \%$ respectively

Table 7: Test results for Hypothesis 2.1 
The adoption of renewable technology is costly with high sunk costs so the availability of finance plays a crucial role. Banking reforms with interest rate liberalization and the development of several non-bank financial institutions (such as cooperatives) might have facilitated easy borrowing and much needed access to funds thereby promoting investments in renewable capacity. An important lesson to be learnt here is that the long run transition towards a low carbon economy with the widespread adoption of renewable is likely to also depend on the overall financial sector reforms in the transition economies.

b) The Technical Impacts of reform: Per capita transmission and distribution losses, per capita overall electricity production. and per capita renewable electricity production were considered as performance outcomes to assess the operational and technical impacts of power sector and other economic institutional reforms. The results obtained from hypotheses tests $(3,4$ and 4.1$)$ are presented and discussed below accordingly.

i) Hypothesis 3: The results from table 8 shows that power sector reform 'on its own' does not have a significant effect on reducing the per capita T\&D losses but inclusion of interactions in the model would do so. The lagged value is also significant implying prior years' losses have significant bearings on current year's losses. Overall market liberalization has significantly increased the T\&D losses in the transition countries. The argument can be supported on the grounds that cross-border power trade has significantly increased in the transition countries after market liberalization. For instance, the SEE region electricity imports increased from $1837 \mathrm{GWh}$ to $5549 \mathrm{GWh}$ between 1995 and 2002.

With old grids waiting for upgrading and maintenance in several countries, power losses might be proportional to the volume of imports (i.e. to the amount of electricity passing through the grid). However, overall market reform when complemented with power sector reform has reduced the T\&D losses across the TECs. One way to counter the inefficiency of power losses would be to harmonize power sector reforms with the overall market reforms (price liberalization, open trading and competition policy) as shown by our results. 


\begin{tabular}{|c|c|c|c|c|c|c|}
\hline \multicolumn{7}{|c|}{ Impact of reforms on per capita transmission and distribution losses } \\
\hline \multirow[t]{2}{*}{ Variables } & \multicolumn{2}{|c|}{ Anderson-Hsiao } & \multicolumn{2}{|c|}{ Arellano-Bond } & \multicolumn{2}{|c|}{ Blundell-Bond } \\
\hline & Model I & Model II & Model I & Model II & Model I & Model II \\
\hline L.LNPTDLS & $\begin{array}{c}0.781^{* * *} \\
(0.065)\end{array}$ & $\begin{array}{c}0.783 * * * \\
(0.066)\end{array}$ & $\begin{array}{c}0.818^{* * *} \\
(0.039)\end{array}$ & $\begin{array}{c}0.809 * * * \\
(0.042)\end{array}$ & $\begin{array}{c}0.928^{* * *} \\
(0.031)\end{array}$ & $\begin{array}{c}0.911^{* * *} \\
(0.036)\end{array}$ \\
\hline PRI & $\begin{array}{l}-0.023 \\
(0.045)\end{array}$ & $\begin{array}{l}-0.180 \\
(0.135)\end{array}$ & $\begin{array}{l}-0.018 \\
(0.026)\end{array}$ & $\begin{array}{l}-0.159 * \\
(0.089)\end{array}$ & $\begin{array}{l}-0.028 \\
(0.027)\end{array}$ & $\begin{array}{c}-0.191^{* *} \\
(0.089)\end{array}$ \\
\hline OIRI & $\begin{array}{c}-0.020 \\
(0.059)\end{array}$ & $\begin{array}{l}-0.053 \\
(0.122)\end{array}$ & $\begin{array}{l}-0.020 \\
(0.032)\end{array}$ & $\begin{array}{l}-0.059 \\
(0.076)\end{array}$ & $\begin{array}{l}-0.009 \\
(0.027)\end{array}$ & $\begin{array}{l}-0.033 \\
(0.078)\end{array}$ \\
\hline EGRI & $\begin{array}{c}-0.004 \\
(0.053)\end{array}$ & $\begin{array}{l}-0.046 \\
(0.124)\end{array}$ & $\begin{array}{l}-0.005 \\
(0.032)\end{array}$ & $\begin{array}{l}-0.048 \\
(0.082)\end{array}$ & $\begin{array}{l}-0.005 \\
(0.034)\end{array}$ & $\begin{array}{l}-0.075 \\
(0.084)\end{array}$ \\
\hline OMLI & $\begin{array}{c}0.065 \\
(0.046)\end{array}$ & $\begin{array}{c}0.202 * * \\
(0.097)\end{array}$ & $\begin{array}{c}0.060 * * \\
(0.027)\end{array}$ & $\begin{array}{c}0.195 * * * \\
(0.066)\end{array}$ & $\begin{array}{c}0.058^{* *} \\
(0.028)\end{array}$ & $\begin{array}{c}0.207^{* * *} \\
(0.067)\end{array}$ \\
\hline FRI & $\begin{array}{l}-0.024 \\
(0.030)\end{array}$ & $\begin{array}{l}-0.031 \\
(0.161)\end{array}$ & $\begin{array}{l}-0.026 \\
(0.030)\end{array}$ & $\begin{array}{l}-0.043 \\
(0.109)\end{array}$ & $\begin{array}{l}-0.032 \\
(0.031)\end{array}$ & $\begin{array}{l}-0.025 \\
(0.107)\end{array}$ \\
\hline LNPECS & $\begin{array}{c}-0.043 \\
(0.074)\end{array}$ & $\begin{array}{c}0.053 \\
(0.068)\end{array}$ & $\begin{array}{l}-0.0489 \\
(0.040)\end{array}$ & $\begin{array}{c}0.053 \\
(0.043)\end{array}$ & $\begin{array}{c}-0.034 \\
(0.038)\end{array}$ & $\begin{array}{c}0.051 \\
(0.040)\end{array}$ \\
\hline $\mathrm{PRI} * \mathrm{OIRI}$ & & $\begin{array}{c}0.025 \\
(0.059)\end{array}$ & & $\begin{array}{c}0.026 \\
(0.038)\end{array}$ & & $\begin{array}{c}0.023 \\
(0.039)\end{array}$ \\
\hline PRI*EGRI & & $\begin{array}{c}0.029 \\
(0.061)\end{array}$ & & $\begin{array}{c}0.029 \\
(0.039)\end{array}$ & & $\begin{array}{c}0.048 \\
(0.041)\end{array}$ \\
\hline $\mathrm{PRI} * \mathrm{OMLI}$ & & $\begin{array}{c}-0.106^{*} \\
(0.090)\end{array}$ & & $\begin{array}{c}-0.105^{* *} \\
(0.040)\end{array}$ & & $\begin{array}{c}-0.118^{* * *} \\
(0.041)\end{array}$ \\
\hline PRI*FRI & & $\begin{array}{c}0.006 \\
(0.081)\end{array}$ & & $\begin{array}{c}0.009 \\
(0.053)\end{array}$ & & $\begin{array}{l}-0.024 \\
(0.036)\end{array}$ \\
\hline
\end{tabular}

$*, * *, * * *$ denotes significance at $10 \%, 5 \%$ and $1 \%$ respectively

Table 8: Test results for Hypothesis 3

ii) Hypothesis 4: Power sector reform significantly affects per capita electricity production only after controlling for possible interaction across different institutional variables. The short history of electricity production (year before) also significantly determines the current year's per capita production across the TECs. Overall market liberalization also seems to have brought about a significant effect in per capita electricity production. Increasing regional power trade with the creation of power exchanges in Europe as a whole coupled with increasing cross border trade of oil and gas (as a fuel to generate electricity) from the energy-rich countries in transition could explain the overall increase in power trade volumes.

Large scale privatization and enterprise restructuring in relation to power sector reforms also produced significant results in overall electricity production as shown in Table 9. 


\begin{tabular}{|c|c|c|c|c|c|c|}
\hline \multicolumn{7}{|c|}{ Impact of reforms on per capita electricity production } \\
\hline \multirow[t]{2}{*}{ Variables } & \multicolumn{2}{|c|}{ Anderson-Hsiao } & \multicolumn{2}{|c|}{ Arellano-Bond } & \multicolumn{2}{|c|}{ Blundell-Bond } \\
\hline & Model I & Model II & Model I & Model II & Model I & Model II \\
\hline L.LNPEPDN & $\begin{array}{l}0.518^{* * *} \\
(0.061)\end{array}$ & $\begin{array}{l}0.519 * * * \\
(0.050)\end{array}$ & $\begin{array}{l}0.578 * * * \\
(0.030)\end{array}$ & $\begin{array}{l}0.809 * * * \\
(0.042)\end{array}$ & $\begin{array}{l}0.810^{* * *} \\
(0.026)\end{array}$ & $\begin{array}{l}0.848^{* * *} \\
(0.029)\end{array}$ \\
\hline PRI & $\begin{array}{l}-0.031 \\
(0.082)\end{array}$ & $\begin{array}{l}0.120 \\
(0.909)\end{array}$ & $\begin{array}{l}-0.003 \\
(0.015)\end{array}$ & $\begin{array}{l}0.133^{*} \\
(0.050)\end{array}$ & $\begin{array}{l}0.015 \\
(0.018)\end{array}$ & $\begin{array}{l}0.159 * * \\
(0.089)\end{array}$ \\
\hline OIRI & $\begin{array}{l}0.019 \\
(0.101)\end{array}$ & $\begin{array}{l}0.089 \\
(0.760)\end{array}$ & $\begin{array}{l}0.019 \\
(0.020)\end{array}$ & $\begin{array}{l}0.086 \\
(0.044)\end{array}$ & $\begin{array}{l}0.011 \\
(0.025)\end{array}$ & $\begin{array}{l}0.150 \\
(0.058)\end{array}$ \\
\hline EGRI & $\begin{array}{l}-0.008 \\
(0.100)\end{array}$ & $\begin{array}{l}-0.073 \\
(0.811)\end{array}$ & $\begin{array}{l}-0.007 \\
(0.017)\end{array}$ & $\begin{array}{l}-0.078 \\
(0.047)\end{array}$ & $\begin{array}{l}-0.017 \\
(0.025)\end{array}$ & $\begin{array}{l}-0.116 \\
(0.063)\end{array}$ \\
\hline OMLI & $\begin{array}{l}-0.007 \\
(0.085)\end{array}$ & $\begin{array}{l}0.062 \\
(0.645)\end{array}$ & $\begin{array}{l}-0.002 \\
(0.017)\end{array}$ & $\begin{array}{l}0.074 * * \\
(0.037)\end{array}$ & $\begin{array}{l}0.026 \\
(0.021)\end{array}$ & $\begin{array}{l}0.084^{*} \\
(0.050)\end{array}$ \\
\hline FRI & $\begin{array}{l}0.026 \\
(0.030)\end{array}$ & $\begin{array}{l}0.010 \\
(1.09)\end{array}$ & $\begin{array}{l}0.024 \\
(0.019)\end{array}$ & $\begin{array}{l}0.012 \\
(0.061)\end{array}$ & $\begin{array}{l}0.019 \\
(0.021)\end{array}$ & $\begin{array}{l}0.019 \\
(0.077)\end{array}$ \\
\hline $\mathrm{PRI} * \mathrm{OIRI}$ & & $\begin{array}{l}-0.031 \\
(0.368)\end{array}$ & & $\begin{array}{l}-0.029 \\
(0.021)\end{array}$ & & $\begin{array}{l}-0.067 \\
(0.029)\end{array}$ \\
\hline PRI*EGRI & & $\begin{array}{l}0.038 \\
(0.396)\end{array}$ & & $\begin{array}{l}0.042^{*} \\
(0.022)\end{array}$ & & $\begin{array}{l}0.057^{*} \\
(0.030)\end{array}$ \\
\hline $\mathrm{PRI} * \mathrm{OMLI}$ & & $\begin{array}{l}-0.055 \\
(0.392)\end{array}$ & & $\begin{array}{l}-0.063 \\
(0.022)\end{array}$ & & $\begin{array}{l}-0.049 \\
(0.041)\end{array}$ \\
\hline PRI*FRI & & $\begin{array}{l}0.013 \\
(0.524\end{array}$ & & $\begin{array}{l}0.011 \\
(0.030)\end{array}$ & & $\begin{array}{l}0.008 \\
(0.036)\end{array}$ \\
\hline
\end{tabular}

iii) Hypothesis 4.1: The test results from table 10 reports that overall market liberalization on its own had a significant negative impact on per capita renewable electricity production. The result is not surprising on the fact that the abundant availability and cross-border movement of conventional energy sources like oil, gas and fuel in the region have installed reluctance among countries to significantly invest in renewable energy sources to improve the overall supply security. The high cost of renewable production could be a barrier to invest in these technologies. The argument is supported on the grounds that financial sector reform on its own significantly affects the per capita renewable electricity production. Earlier results on financial sector reform significantly affecting the per capita installed renewable electricity capacity provide some evidence of robustness to this finding.

Model II suggests that the interaction between power sector reform and other infrastructures reform can significantly influence per capita renewable electricity production. The TECs primarily rely on hydro as a major source of renewable energy and reforms in the water sector (included under other infrastructure) have 
important bearings. On the other hand, per capita overall electricity consumption being insignificant to per capita renewable electricity production imply that there is not much demand for renewable electricity in the transition countries at a first place $^{27}$. The lagged value is significant following earlier results.

\begin{tabular}{|c|c|c|c|c|c|c|}
\hline \multicolumn{7}{|c|}{ Impact of reforms on per capita renewable electricity production } \\
\hline \multirow[t]{2}{*}{ Variables } & \multicolumn{2}{|c|}{ Anderson-Hsiao } & \multicolumn{2}{|c|}{ Arellano-Bond } & \multicolumn{2}{|c|}{ Blundell-Bond } \\
\hline & Model I & Model II & Model I & Model II & Model I & Model II \\
\hline L.LNPREPDN & $\begin{array}{l}0.710^{* * *} \\
(0.046)\end{array}$ & $\begin{array}{l}0.729 * * * \\
(0.044)\end{array}$ & $\begin{array}{l}0.701^{* * *} \\
(0.029)\end{array}$ & $\begin{array}{l}0715^{* * *} \\
(0.031)\end{array}$ & $\begin{array}{l}0.759 * * * \\
(0.027)\end{array}$ & $\begin{array}{l}0.779 * * * \\
(0.028)\end{array}$ \\
\hline PRI & $\begin{array}{l}-0.082 \\
(0.061)\end{array}$ & $\begin{array}{l}-0.296 \\
(0.250)\end{array}$ & $\begin{array}{l}-0.087 \\
(0.055)\end{array}$ & $\begin{array}{l}-0.300 \\
(0.222)\end{array}$ & $\begin{array}{l}-0.070 \\
(0.064)\end{array}$ & $\begin{array}{l}-0.250 \\
(0.254)\end{array}$ \\
\hline OIRI & $\begin{array}{l}-0.111 \\
(0.080)\end{array}$ & $\begin{array}{l}-0.541 \\
(0.214)\end{array}$ & $\begin{array}{l}-0.093 \\
(0.068)\end{array}$ & $\begin{array}{l}-0.494 \\
(0.205)\end{array}$ & $\begin{array}{l}-0.165 \\
(0.080)\end{array}$ & $\begin{array}{l}-0.702 \\
(0.227)\end{array}$ \\
\hline EGRI & $\begin{array}{l}0.137 \\
(0.093)\end{array}$ & $\begin{array}{l}0.440 \\
(0.202)\end{array}$ & $\begin{array}{l}0.135 \\
(0.085)\end{array}$ & $\begin{array}{l}0.394 \\
(0.197)\end{array}$ & $\begin{array}{l}0.159 \\
(0.100)\end{array}$ & $\begin{array}{l}0.553 \\
(0.224)\end{array}$ \\
\hline OMLI & $\begin{array}{l}-0.163^{*} \\
(0.089)\end{array}$ & $\begin{array}{l}-0.259 \\
(0.196)\end{array}$ & $\begin{array}{l}-0.170 * * \\
(0.076)\end{array}$ & $\begin{array}{l}-0.250 \\
(0.187)\end{array}$ & $\begin{array}{l}-0.153 \\
(0.088)\end{array}$ & $\begin{array}{l}-0.304 \\
(0.210)\end{array}$ \\
\hline FRI & $\begin{array}{l}0.216^{* *} \\
(0.030)\end{array}$ & $\begin{array}{l}0.254 \\
(0.279)\end{array}$ & $\begin{array}{l}0.218^{* * *} \\
(0.083)\end{array}$ & $\begin{array}{l}0.245 \\
(0.268)\end{array}$ & $\begin{array}{l}0.200 * * \\
(0.093)\end{array}$ & $\begin{array}{l}0.350 \\
(0.297)\end{array}$ \\
\hline LNPECS & $\begin{array}{l}0.208 \\
(0.163)\end{array}$ & $\begin{array}{l}0.178 \\
(0.163)\end{array}$ & $\begin{array}{l}0.204 \\
(0.150)\end{array}$ & $\begin{array}{l}0.188 \\
(0.153)\end{array}$ & $\begin{array}{l}0.223 \\
(0.172)\end{array}$ & $\begin{array}{l}0.211 \\
(0.169)\end{array}$ \\
\hline $\mathrm{PRI}{ }^{*} \mathrm{OIRI}$ & & $\begin{array}{l}0.219^{* *} \\
(0.101)\end{array}$ & & $\begin{array}{l}0.199 * * \\
(0.098)\end{array}$ & & $\begin{array}{l}0.284^{* *} \\
(0.109)\end{array}$ \\
\hline $\mathrm{PRI}{ }^{*} \mathrm{EGRI}$ & & $\begin{array}{l}-0.180 \\
(0.111)\end{array}$ & & $\begin{array}{l}-0.150 \\
(0.107)\end{array}$ & & $\begin{array}{l}-0.234 \\
(0.121)\end{array}$ \\
\hline $\mathrm{PRI} * \mathrm{OMLI}$ & & $\begin{array}{l}0.085 \\
(0.102)\end{array}$ & & $\begin{array}{l}0.078 \\
(0.097)\end{array}$ & & $\begin{array}{l}0.105 \\
(0.111)\end{array}$ \\
\hline PRI*FRI & & $\begin{array}{l}-0.038 \\
(0.135)\end{array}$ & & $\begin{array}{l}-0.040 \\
(0.127)\end{array}$ & & $\begin{array}{l}-0.092 \\
(0.141)\end{array}$ \\
\hline
\end{tabular}

$*, * *, * * *$ denotes significance at $10 \%, 5 \%$ and $1 \%$ respectively

Table 10: Test results for Hypothesis 4.1

c) The Environmental Impacts of Reform: Carbon emission intensity and energy consumption intensity were considered as a measure to assess the environmental impacts of power sector reforms and wider economic reforms since 1990. Hypotheses 5 and 6 were tested with the results being presented below:

i) Hypothesis 5: The test results on carbon emission intensity in table 11 show that all other institutional variables except for reforms in other infrastructure have no significant bearing on carbon emissions intensity. Water sector reforms can to some

${ }^{27}$ It may also mean that renewable electricity capacity is not connected to the grid. 
extent also detect the use of water to generate electricity while hydroelectricity has been the dominant from of renewable energy sources in the transition countries. Thus, progress in water sector reforms may mean a reduction the carbon intensity. However, water sector reforms on its own are unable to influence the emissions intensity.

Per capita electricity consumption in the transition countries has also been driving the emission intensity as nuclear and thermal sources dominate electricity generation across these countries as shown by our results. Likewise, the previous level of carbon intensity also has a role to play in determining the current level of intensity with the lagged coefficient being significant.

\begin{tabular}{|c|c|c|c|c|c|c|}
\hline \multicolumn{7}{|c|}{ Impact of reforms on carbon emissions intensity } \\
\hline \multirow[t]{2}{*}{ Variables } & \multicolumn{2}{|c|}{ Anderson-Hsiao } & \multicolumn{2}{|c|}{ Arellano-Bond } & \multicolumn{2}{|c|}{ Blundell-Bond } \\
\hline & Model I & Model II & Model I & Model II & Model I & Model II \\
\hline L.LCEI & $\begin{array}{c}0.892^{* * *} \\
(0.040)\end{array}$ & $\begin{array}{c}0.832 * * * \\
(0.038)\end{array}$ & $\begin{array}{c}0.890 * * * \\
(0.030)\end{array}$ & $\begin{array}{c}0.866^{* * *} \\
(0.018)\end{array}$ & $\begin{array}{c}0.852^{* * *} \\
(0.026)\end{array}$ & $\begin{array}{c}0.897 * * * \\
(0.027)\end{array}$ \\
\hline PRI & $\begin{array}{l}-0.022 \\
(0.023)\end{array}$ & $\begin{array}{l}-0.425 \\
(0.393)\end{array}$ & $\begin{array}{c}0.042 \\
(0.078)\end{array}$ & $\begin{array}{l}-0.186 \\
(0.069)\end{array}$ & $\begin{array}{c}0.059 \\
(0.081)\end{array}$ & $\begin{array}{l}-0.197 \\
(0.027)\end{array}$ \\
\hline OIRI & $\begin{array}{c}-0.051 \\
(0.094)\end{array}$ & $\begin{array}{l}-0.564^{*} \\
(0.029)\end{array}$ & $\begin{array}{l}-0.115 \\
(0.030)\end{array}$ & $\begin{array}{c}-0.059 * * \\
(0.070)\end{array}$ & $\begin{array}{l}-0.128 \\
(0.027)\end{array}$ & $\begin{array}{c}-0.553^{* *} \\
(0.066)\end{array}$ \\
\hline EGRI & $\begin{array}{c}0.193 \\
(0.014)\end{array}$ & $\begin{array}{c}0.180 \\
(0.034)\end{array}$ & $\begin{array}{c}0.132 \\
(0.090)\end{array}$ & $\begin{array}{l}0.0157 \\
(0.052)\end{array}$ & $\begin{array}{c}0.142 \\
(0.094)\end{array}$ & $\begin{array}{c}0.148 \\
(0.062)\end{array}$ \\
\hline OMLI & $\begin{array}{l}-0.025 \\
(0.013)\end{array}$ & $\begin{array}{c}-0.134 \\
(0.079)\end{array}$ & $\begin{array}{c}0.014 \\
(0.078)\end{array}$ & $\begin{array}{c}0.080 \\
(0.219)\end{array}$ & $\begin{array}{c}0.033 \\
(0.081)\end{array}$ & $\begin{array}{c}0.059 \\
(0.224)\end{array}$ \\
\hline FRI & $\begin{array}{c}-0.154 \\
(0.140)\end{array}$ & $\begin{array}{c}0.124 \\
(0.338)\end{array}$ & $\begin{array}{l}-0.151 \\
(0.119)\end{array}$ & $\begin{array}{l}-0.056 \\
(0.269)\end{array}$ & $\begin{array}{l}-0.161 \\
(0.122)\end{array}$ & $\begin{array}{l}-0.020 \\
(0.273)\end{array}$ \\
\hline LNPECS & $\begin{array}{l}0.327^{*} \\
(0.080)\end{array}$ & $\begin{array}{l}0.323^{*} \\
(0.088)\end{array}$ & $\begin{array}{c}0.028 * * * \\
(0.034)\end{array}$ & $\begin{array}{c}0.338^{* *} \\
(0.032)\end{array}$ & $\begin{array}{c}0.369 * * * \\
(0.041)\end{array}$ & $\begin{array}{c}0.353^{* *} \\
(0.043)\end{array}$ \\
\hline $\mathrm{PRI} * \mathrm{OIRI}$ & & $\begin{array}{c}0.205 \\
(0.047)\end{array}$ & & $\begin{array}{c}0.210 \\
(0.021)\end{array}$ & & $\begin{array}{c}0.192 \\
(0.025)\end{array}$ \\
\hline PRI*EGRI & & $\begin{array}{c}0.007 \\
(0.060)\end{array}$ & & $\begin{array}{l}-0.007 \\
(0.034)\end{array}$ & & $\begin{array}{c}0.001 \\
(0.037)\end{array}$ \\
\hline $\mathrm{PRI} * \mathrm{OMLI}$ & & $\begin{array}{c}0.136 \\
(0.060)\end{array}$ & & $\begin{array}{l}-0.001 \\
(0.030)\end{array}$ & & $\begin{array}{c}0.022 \\
(0.035)\end{array}$ \\
\hline PRI*FRI & & $\begin{array}{l}-0.179 \\
(0.060)\end{array}$ & & $\begin{array}{l}-0.083 \\
(0.029)\end{array}$ & & $\begin{array}{l}-0.101 \\
(0.043)\end{array}$ \\
\hline
\end{tabular}

ii) Hypothesis 6: Apart from the lagged value being significant, power sector reform on its own did not yield a significant impact on energy intensity. However, EGRI is significant in increasing energy intensity as large scale privatization can increase 
overall industrial activities in an economy raising overall energy demand. Likewise, energy intensity also remains inelastic to all other institutional variables. However, accounting for the interactions among certain institutional variables as per model II, reforms in power sector and reforms in other infrastructure had a negative significant impact on energy intensity. Energy intensity is a direct measure of energy efficiency and meaningful reforms of the power sector and other infrastructures that heavily rely on electricity can significantly reduce the energy intensity by promoting a rational consumption of energy as shown in Table 12.

\begin{tabular}{|c|c|c|c|c|c|c|}
\hline \multicolumn{7}{|c|}{ Impact of reforms on energy intensity } \\
\hline \multirow[t]{2}{*}{ Variables } & \multicolumn{2}{|c|}{ Anderson-Hsiao } & \multicolumn{2}{|c|}{ Arellano-Bond } & \multicolumn{2}{|c|}{ Blundell-Bond } \\
\hline & Model I & Model II & Model I & Model II & Model I & Model II \\
\hline L.LEI & $\begin{array}{c}0.833^{* * *} \\
(0.045)\end{array}$ & $\begin{array}{c}0.863^{* * *} \\
(0.042)\end{array}$ & $\begin{array}{c}0.855^{* * *} \\
(0.037)\end{array}$ & $\begin{array}{c}0.851^{* * *} \\
(0.042)\end{array}$ & $\begin{array}{c}0.982 * * * \\
(0.028)\end{array}$ & $\begin{array}{c}0.924^{* * *} \\
(0.031)\end{array}$ \\
\hline PRI & $\begin{array}{c}0.024 \\
(0.022)\end{array}$ & $\begin{array}{l}-0.273^{*} \\
(0.097)\end{array}$ & $\begin{array}{c}0.023 \\
(0.016)\end{array}$ & $\begin{array}{l}-0.046^{*} \\
(0.075)\end{array}$ & $\begin{array}{c}0.027 \\
(0.017)\end{array}$ & $\begin{array}{c}-0.077^{*} \\
(0.081)\end{array}$ \\
\hline OIRI & $\begin{array}{l}-0.053 \\
(0.022)\end{array}$ & $\begin{array}{c}-0.133^{* *} \\
(0.114)\end{array}$ & $\begin{array}{c}-0.064^{* * *} \\
(0.020)\end{array}$ & $\begin{array}{c}-0.165^{* *} \\
(0.056)\end{array}$ & $\begin{array}{c}-0.047^{* *} \\
(0.021)\end{array}$ & $\begin{array}{c}-0.115^{*} \\
(0.061)\end{array}$ \\
\hline EGRI & $\begin{array}{l}0.051^{*} \\
(0.030)\end{array}$ & $\begin{array}{c}0.097 \\
(0.074)\end{array}$ & $\begin{array}{c}0.047^{* *} \\
(0.022)\end{array}$ & $\begin{array}{c}0.088 \\
(0.055)\end{array}$ & $\begin{array}{c}0.050 * * \\
(0.023)\end{array}$ & $\begin{array}{c}0.077 \\
(0.058)\end{array}$ \\
\hline OMLI & $\begin{array}{l}-0.023 \\
(0.022)\end{array}$ & $\begin{array}{l}-0.228 \\
(0.070)\end{array}$ & $\begin{array}{l}-0.031 \\
(0.019)\end{array}$ & $\begin{array}{l}-0.069 \\
(0.050)\end{array}$ & $\begin{array}{l}-0.017 \\
(0.020)\end{array}$ & $\begin{array}{c}0.057 \\
(0.072)\end{array}$ \\
\hline FRI & $\begin{array}{l}-0.027 \\
(0.031)\end{array}$ & $\begin{array}{c}0.159 \\
(0.083)\end{array}$ & $\begin{array}{l}-0.031 \\
(0.022)\end{array}$ & $\begin{array}{c}0.023 \\
(0.067)\end{array}$ & $\begin{array}{c}-0.012 \\
(0.024)\end{array}$ & $\begin{array}{c}1776.14 \\
(4766.55)\end{array}$ \\
\hline $\mathrm{PRI}{ }^{*} \mathrm{OIRI}$ & & $\begin{array}{c}0.047 \\
(0.039)\end{array}$ & & $\begin{array}{c}0.048 \\
(0.028)\end{array}$ & & $\begin{array}{c}0.032 \\
(0.031)\end{array}$ \\
\hline PRI*EGRI & & $\begin{array}{l}-0.017 \\
(0.040)\end{array}$ & & $\begin{array}{l}-0.024 \\
(0.029)\end{array}$ & & $\begin{array}{l}-0.017 \\
(0.030)\end{array}$ \\
\hline $\mathrm{PRI} * \mathrm{OMLI}$ & & $\begin{array}{c}0.134 \\
(0.050)\end{array}$ & & $\begin{array}{c}0.029 \\
(0.033)\end{array}$ & & $\begin{array}{c}0.047 \\
(0.036)\end{array}$ \\
\hline PRI*FRI & & $\begin{array}{l}-0.083 \\
(0.039)\end{array}$ & & $\begin{array}{c}-0.031 \\
(0.029)\end{array}$ & & $\begin{array}{l}-0.036 \\
(0.031)\end{array}$ \\
\hline
\end{tabular}

\subsection{Summary of results}

The results from the hypotheses tests reveal mixed findings. In most cases as shown by earlier results; power sector reform did not directly influence the outcomes related to the power sector. The reasons could be because of: a) although reforms have been agreed on paper; the implementation of reforms have been rather weak to influence any outcome significantly b) the complexities and intricacies of power sector reform and as a part of wider economic reform was not understood or largely 
ignored and c) the 19 years' time-frame considered in our study is still not sufficient enough to capture the effectiveness of the reform process across the TECs.

The legacy of central planning may have translated into slow willingness towards reform. The first post-communist governments in some SEE (Belarus) and many CIS countries (Turkmenistan and Uzbekistan) were led by the same political elites under communism delaying the overall progress in transition to preserve their status-quo. Elsewhere in Bosnia and Herzegovina, FR Yugoslavia and Tajikistan; overall reforms including the reforms in the power sector has been slower as these countries had to do some 'catch up' due to civil war and ethnic-conflicts. Regional integration via EU membership have successfully catapulted power sector reforms as these countries with common geography, history and culture created the appropriate institutions that allowed international integration to complement domestic reforms.

It is also evident from our results that the relationship between power sector reforms and power sector outcomes is not straightforward or linear and only tends to work under well-defined overall institutional framework. For instance, adding new renewable generation capacity and hence increasing the production of renewable energy is only successful when supported by the broader financial sector reforms and reforms in other infrastructures (that includes the water sector). In line with Easterly and Levine (2003), our results support the view that power sector reforms where successful are only able to do so by adopting broader institutional framework to support the reforms.

However, the result is always not automatic or guaranteed. Countries such as Albania, Bosnia and Herzegovina, Georgia and Tajikistan though have infantry institution development as per the EBRD score have not lost much in terms of power sector outcomes such as energy intensity and emissions intensity primarily because of a) large hydro plants as renewable resources ${ }^{28}$ and b) less energy-intensive industries. Nonetheless, one important lesson to be learnt is that the implementation democratic market-oriented reforms in the absence of appropriate institutions may not produce the desired consequences. The results also to some extent supports the view that 'gradualism' with proper reforms sequencing can perform better than hastily applied 'shock therapy reforms'.

It is necessary for policymakers to understand that not everything is important and everything should not be done at once. For example, misguided large scale privatization under weak governance structure created and preserved vested interests in the Russian power sector. Our results in general show a negative

${ }^{28}$ For Albania and Georgia, the share of renewable electricity generated from renewable sources exceeds 80 percent. 
significant relationship between economic governance index and per capita generation capacity.

\section{Conclusions}

The aim of this paper was to explore the link or association between between power sector reforms and wider economic reforms in assessing the macroeconomic and the power sector outcomes (economic, operational and environmental) across the transition countries. We focused on the relatively ignored role of institutions that market oriented policies tend to heavily rely upon to work better than solely relying on prices as assumed under the neoclassical theory. Our findings from the econometric analysis were also based on the composite 'institutional indexes' constructed accordingly. While the construction of such institutional index might vary across research and econometric methodology as per the discretion of the researchers; the essence of our results is expected to be preserved to a large extent.

The results support the view that electricity sector reform is indeed a complicated process primarily due to its dependency upon broader institutional framework in the economy. The link or association between power sector reforms and other institutional reform is not as lucid and direct as policymakers would have liked. Thus, a failure to understand the institutional aspects of electricity sector reform combined with adopting emulated reforms under differing institutional capacity delayed the process of reform being effective. The effects from successful electricity reform experiences was a good opportunity to learn but under differing institutional contexts which the transition countries failed to internalize immediately. Thus, the need to formulate priority driven reforms rather than theory driven reforms based on individual capacity, resources and needs is what the developing world can learn from the ongoing massive reform experiment in the TECs. On this note, it is critical if the benchmark set to the transition countries to achieve the standards of that of an industrialized economy (Norway, UK, etc.) is a valid one.

Nonetheless, the learning from the lessons of reforms within the transition countries is being actively pursued as many countries seem to have sped up their power sector reforms post 2000 though with stagnation witnessed after 2005. While so much has been said in the past regarding the pacing and sequencing of power sector reforms (i.e. intra sector reforms); the message is clear from our study that only those countries that have been able to synchronize reforms across sectors (i.e. harmonizing power sector reforms with other institutional) reforms or in the process of doing so have gained significantly in terms of power sector and broader macroeconomic outcomes. The main lesson to be learnt by the rest of the developing world is electricity sector reform falls within the domain of wider 
economic reforms. Thus, overall health of economic institutions and the rigidity of the institutional framework matters for power sector reforms to succeed as a whole. 


\section{References:}

Arrow, K. (1972). Gifts and Exchanges, Philosophy and Public Affairs, 1(4), pp. 343362.

Bacon, R.W. and Besant-Jones, J. (2001). Global electric Power Reform, Privatization and Liberalization of the Electric Power Industry in Developing Countries, Annual Review of Energy and Environment, Vol.(26), pp. 331-359.

Bruno, G.S.F. (2005). Estimation and Inference in Dynamic Unbalanced Panel data Models with a Small Number of Individuals, CESFRI Working paper 165, February, Milan, Italy.

Bun, J.G and Kiviet, J.F. (2003).On the Diminishing Returns of higher Order Terms in Asymptotic Expansions of Bias. Economics Letters, Vol. 79, pp.145-152.

CDIAC (2005). Carbon Dioxide Information Analysis Center, Oak Ridge, Tennessee, United States.

Easterly, W. and Levine, R. (2003). Tropics, Germs, and Crops: How Endowments Influence Economic Development, Journal of Monetary Economics, Vol. 50, pp.3-39.

Estache, A., Foster, V. and Wodon, Q. (2002). Making Infrastructure reform in Latin America Work for the Poor, CEPAL Review 78, December, pp. 101-118.

EIA (2005). Energy Information Administration, Washington, DC, United States.

World Bank (1999). Global Energy Sector reform in Developing Countries, Report no. 219/99, Energy Sector Management Assistance Program, Washington, DC.

EBRD (2001). Energy in Transition, Transition report 2001, European bank for Reconstruction and Development, London.

EBRD (2008). Securing Sustainable Energy in Transition Economies, Transition Report, European Bank for Reconstruction and Development, April, London.

Fukuyama, F. (1995). Trust, Free Press, New York.

Gray, D.(1995). Reforming the Energy Sector in Transition Economies, World Bank Discussion Papers, No. 296, Washington, DC. 
Hattori, T. and Tsutui, M (2004). Economic Impacts of Regulatory Reforms in the Electricity Supply Industry: A Panel Data Analysis of OECD Countries, Energy Policy, Vol (32), pp:823-832.

Heybey, B. and Murrell. (1999). The Relationship between economic Growth and Speed of Liberalization during Transition, Journal of Economic Policy Reform, Vol. 3(2), pp. 121-132.

Hirschhausen, C.V and Waelde, W.T. (2001). The End of Transition: An Institutional Interpretation of energy Sector Reform in Eastern Europe and CIS, MOCT-MOST: Economic Policy in Transitional Economies, 11(1), pp.93-110.

Hirschmann, O.A. (1992).Rival Views of Market Society, Harvard University Press, Cambridge.

Hogan, W. W. (2001). Designing Market Institutions for Electric Network Systems: Reforming the Reforms in New Zealand and the US, Center for Business and Government, John F. Kennedy School of Government, Harvard University, Massachusetts, USA.

Im, S.K., Paseran, M.H. and Shin, Y. (1995). Testing for Unit Roots in Heterogeneous Panels, Journal of Econometrics, Vol.15 (1), pp.53-74.

Jamasb, T., Mota, R., Newberry, D., and Pollitt, M.(2004). Electricity Sector reform in Developing Countries: A survey of empirical evidence on determinants and performance, Cambridge Working Papers in Economics, CWPE 0439, Cambridge, UK.

Jamasb, T. (2004). Between the State and Market: Electricity Sector reform in Developing Countries, Utilities Policy, pp. 14-30.

Jhirad, D.(1990). Power Sector Innovation in developing Countries: Implementing multifaceted Solutions, Annual Review of Energy and Environment, Vol.15, pp.365398.

Joskow, P. (1998). Electricity Sectors in Transition, The Energy Journal, Vol. 19(2), pp.25-52.

Kiviet, J.F. (1995). On Bias, Inconsistency and Efficiency of Various Estimators in Dynamic Panel Data Models, Journal of Econometrics, Vol. 68, pp. 53-78. 
Kennedy, D.(2003). Power Sector Regulatory Reform in Transition Economies: Progress and Lesson learned, European Bank for Reconstruction and Development (EBRD), Working Paper No. 78, February.

Levy, B. and Spiller, P. (1996). Regulations, Institutions and Commitment: Comparative studies of Telecommunications, Cambridge University Press, Cambridge.

Newberry, D.(1994). Restructuring and Privatizing Electric Utilities in Eastern Europe, Economics of Transition, Vol.2 (3), pp.291-417.

North, D.C. (1971). Institutional Change and Economic Growth, The Journal of Economic History, Cambridge University Press, vol. 31(01), pp. 118-125, March.

North, D.C.(1994). Economic Performance through Time, American Economic Review, Vol. 84(3), pp.359-368.

Pittman, R. (2003). Vertical Restructuring (or not) of the Infrastructure sectors of Transition Economies, Journal of Industry, Competition and Trade, Vol. 3(1-2), pp.526.

Pollitt, M. (2009). Evaluating the Evidence on Electricity Reform: Lessons for the South East Europe (SEE) Market, Utilities Policy, Vol.17, pp.13-23.

Putnam, R. (1993). Making Democracy Work, Princeton University Press, Princeton.

Roodman, D. (2006). How to do xtabond2: An Introduction to 'Difference' and 'System' GMM in Stata, Working Paper 103, Center for Global Development, December, Washington, DC, United States.

Rodrik, D., Subramanian, A. and F. Trebbi. (2004). Institutions Rule: The Primacy of Institutions over Geography and Integration in Economic Development, Journal of Economic Growth, Vol. 9 (2), June, pp. 131-165.

Rufin, C. and Rangan, U.S (2004). Institutional Change in the Electricity Industry: Initial Evidence, Babson College Working Paper.

Sen, A. and Jamasb, T.(2010). The Economic Effects of Electricity Deregulation: An Empirical Analysis of Indian States, Cambridge Working Paper Economics 1005, University of Cambridge, UK. 
Steiner, F.(2001).Industry Structure and Performance in the Electricity Supply Industry, OECD Economic Studies, Vol 32(I), pp. 143-182.

Stern, J. (1997). What makes an Independent Regulator Independent? Business Strategy Review, Vol. 8(2), pp.67-74.

Stern, J. (1998). Regulatory Governance: Criteria for Assessing the Performance of Regulatory Systems, Regulation Initiative Discussion Papers, London Business School.

Stern, J. and Davis, R.J. (1998). Economic Reform of Electricity Industries in central and Eastern Europe, Economics of Transition, Vol. 6(2), pp.427-460.

Stiglitz, J. (1999). Whither Reform? Ten Years of Transition, Paper Presented at the Annual Bank Conference on Development Economics, Washington DC, April, pp. 127171.

Williams J.H and Ghandan, R. (2006). Electricity reform in Developing and Transition Countries: A Reappraisal, Energy, 31(6-7), pp. 815-844.

Williamson, O.E. (1975). Markets and Hierarchies: Analysis and Antitrust Implications: A Study in the Economics of Internal Organization, University of Illinois at Urbana-Champaign's Academy for Entrepreneurial Leadership Historical Research Reference in Entrepreneurship, SSRN Working Paper, 2009.

Williamson, O.E. (1996). Transaction cost economics and the Carnegie connection, Journal of Economic Behavior \& Organization, Vol. 31(2), November, pp.149-155.

Zhang, Y.F., Parker, D. and Kirkpatrick, C.(2008). Electricity Sector reform in developing Countries: An Econometric Assessment of the Effects of Privatization, Competition and Regulation, Journal of Regulatory Economics, Vol. (33), pp.159-178. 


\section{Appendix I:}

Table A: Statistics on Resource dependence for selected TECs in 2000 Source: Adapted from EBRD (2001)

\begin{tabular}{|l|l|l|l|l|l|}
\hline & Azerbaijan & Kazakhstan & Russia & Turkmenistan & Uzbekistan \\
\hline $\begin{array}{l}\text { Oil and gas export (\% of } \\
\text { total exports) }\end{array}$ & 85.2 & 46.8 & 50.4 & 81 & 12.3 \\
\hline $\begin{array}{l}\text { Oil and gas export(\% of } \\
\text { total GDP) }\end{array}$ & 30.5 & 24.7 & 21.5 & 68.7 & 4.3 \\
\hline
\end{tabular}

Table B: GDP and Energy Consumption (1990-1994)

Source: Adapted from Gray (1995)

\begin{tabular}{|l|l|l|l|l|l|}
\hline Groups & 1990 & 1991 & 1992 & 1993 & 1994 \\
\hline CEE GDP & -1.1 & -10.3 & -4.1 & 0.6 & 4.7 \\
\hline CEE Energy Consumption & -2.1 & -9.6 & -4.1 & -1.6 & 0.7 \\
\hline Russia GDP & -2.0 & -9.0 & -19.0 & -11.9 & -14.9 \\
\hline Russia Energy Consumption & 0.8 & -1.8 & -6.7 & -6.6 & -9.9 \\
\hline FSU GDP & -2.3 & -9.1 & -18.2 & -9.7 & -15.8 \\
\hline FSU Energy Consumption & 1.9 & -2.4 & -8.0 & -8.7 & -10.4 \\
\hline
\end{tabular}

Table C: Net imports of electricity in selected TECs in TWh from 1988-94 Source: Adapted from Stern and Davis (1997)

\begin{tabular}{|l|l|l|l|}
\hline Countries & 1988 & 1992 & 1994 \\
\hline Hungary & +11.3 & +7.3 & 33.5 \\
\hline Poland & +4.5 & -2.5 & 135.3 \\
\hline Bulgaria & +4.5 & +2.1 & -0.1 \\
\hline Romania & +7.2 & +7.0 & +0.7 \\
\hline Russia & na & 1008.5 & 875.9 \\
\hline Ukraine & na & 255.5 & 209.1 \\
\hline Kazakhstan & na & 82.7 & 66.8 \\
\hline
\end{tabular}

Table D: Prices, cash collections and commercial losses in selected TECs

Source: Adapted from Kennedy (2001)

\begin{tabular}{|l|l|l|l|l|}
\hline Countries & $\begin{array}{l}\text { Residential } \\
\text { price (USc/kwh) }\end{array}$ & $\begin{array}{l}\text { Industrial price } \\
\text { (USc/kwh) }\end{array}$ & $\begin{array}{l}\text { Bill collection } \\
(\%)\end{array}$ & $\begin{array}{l}\text { Commercial } \\
\text { losses (\%) }\end{array}$ \\
\hline Albania & 2.9 & 7.2 & 84.5 & 11.2 \\
\hline Armenia & 4.4 & 2.9 & 87 & 30 \\
\hline Estonia & 4.9 & 4.1 & 97.1 & 1.1 \\
\hline Hungary & 6.8 & 5.7 & 90 & na \\
\hline Romania & 5.2 & 4.8 & 62 & 2 \\
\hline Bulgaria & 3.7 & 3.9 & 85 & 10 \\
\hline Bosnia and Herzegovina & 5.6 & 6.1 & 95 & 11.5 \\
\hline Georgia & 4.2 & 3.3 & 32 & 27.5 \\
\hline Tajikistan & 0.2 & 1.1 & na & 14 \\
\hline Uzbekistan & 0.7 & 0.7 & 25 & na \\
\hline Turkmenistan & 0.5 & 0.5 & 30 & na \\
\hline
\end{tabular}


Table E: Correlation matrix for the independent variables

\begin{tabular}{|l|l|l|l|l|l|l|}
\hline & PRI & OIRI & EGRI & OMLI & FRI & LNPECS \\
\hline PRI & 1.00 & \multicolumn{7}{|l|}{$\mid$} \\
\hline OIRI & 0.53 & 1.00 & & & \\
\hline EGRI & 0.34 & 0.52 & 1.00 & & \\
\hline OMLI & 0.43 & 0.57 & 0.36 & 1.00 & & \\
\hline FRI & 0.38 & 0.65 & 0.58 & 0.31 & 1.00 & \\
\hline LNPECS & 0.19 & 0.28 & 0.22 & 0.10 & 0.32 & 1.00 \\
\hline
\end{tabular}

At $1 \%$, the critical value is -1.96 .

Table F: Results for 'IPShin' panel unit root tests

\begin{tabular}{|l|l|l|l|l|l|l|l|}
\hline Variables & LNPINSTC & LNPRINSTC & LNPGDP & LNPEPDN & LNPREPDN & LNPECS & LNPTDLS \\
\hline $\begin{array}{l}\text { t-bar } \\
\text { statistics }\end{array}$ & -2.375 & -2.963 & -2.940 & -2.571 & -2.373 & -2.370 & -2.178 \\
\hline
\end{tabular}


Appendix II:

\begin{tabular}{|c|c|c|c|c|}
\hline \multicolumn{5}{|c|}{ Hypothesis 1} \\
\hline Estimator & Test & $\mathrm{HO}$ & 1 & II \\
\hline \multirow[t]{3}{*}{$A B$} & $\begin{array}{c}1^{\text {st }} \text { order } \\
\text { autocorrelation }\end{array}$ & $\begin{array}{c}\text { No } \\
\text { autocorrelation }\end{array}$ & $\begin{array}{c}Z=-4.58 \\
\text { Prob }>z=0.000\end{array}$ & $\begin{array}{c}Z=-4.54 \\
\operatorname{Pr}>z=0.000\end{array}$ \\
\hline & $\begin{array}{c}2^{\text {nd }} \text { order } \\
\text { autocorrelation }\end{array}$ & $\begin{array}{c}\text { No } \\
\text { autocorrelation }\end{array}$ & $\begin{array}{c}Z=-1.00 \\
\text { Prob }>z=0.316\end{array}$ & $\begin{array}{c}Z=-0.90 \\
\operatorname{Pr}>z=0.3691\end{array}$ \\
\hline & $\begin{array}{c}\text { Sargan Test of } \\
\text { Overid. Restriction }\end{array}$ & & Prob $>$ Chi2 $=0.005$ & Prob>chi2 $=0.048$ \\
\hline \multirow[t]{3}{*}{ BB } & $\begin{array}{l}A B \text { test for } A R(1) \\
\text { in first differences }\end{array}$ & $\begin{array}{c}\text { No } \\
\text { autocorrelation }\end{array}$ & $\begin{array}{c}Z=-4.56 \\
\text { Prob }>z=0.000\end{array}$ & $\begin{array}{c}Z=-4.62 \\
\text { Prob }>z=0.000\end{array}$ \\
\hline & $\begin{array}{l}A B \text { test for } A R(2) \\
\text { in first differences }\end{array}$ & $\begin{array}{c}\text { No } \\
\text { autocorrelation }\end{array}$ & $\begin{array}{c}Z=-0.77 \\
\text { Prob }>z=0.443\end{array}$ & $\begin{array}{c}Z=-0.88 \\
\text { Prob }>z=0.380\end{array}$ \\
\hline & $\begin{array}{l}\text { Sargan Test of } \\
\text { Overid. } \\
\text { restrictions }\end{array}$ & & $\begin{array}{c}\text { Chi2 }(169)=735.65 \\
\text { Prob }>\text { chi2 }=0.004\end{array}$ & $\begin{array}{l}\text { Chi2 }(169)=639.18 \\
\text { Prob }>\text { chi2 }=0.006\end{array}$ \\
\hline
\end{tabular}

\begin{tabular}{|c|c|c|c|c|}
\hline \multicolumn{5}{|c|}{ Hypothesis 2} \\
\hline Estimator & Test & $\mathrm{HO}$ & 1 & II \\
\hline \multirow[t]{3}{*}{$A B$} & $\begin{array}{c}1^{\text {st }} \text { order } \\
\text { autocorrelation }\end{array}$ & $\begin{array}{c}\text { No } \\
\text { autocorrelation }\end{array}$ & $\begin{array}{c}Z=-8.33 \\
\text { Prob }>z=0.000\end{array}$ & $\begin{array}{c}Z=-8.27 \\
\operatorname{Pr}>z=0.000\end{array}$ \\
\hline & $\begin{array}{c}2^{\text {nd }} \text { order } \\
\text { autocorrelation }\end{array}$ & $\begin{array}{c}\text { No } \\
\text { autocorrelation }\end{array}$ & $\begin{array}{c}\mathrm{Z}=-0.05 \\
\text { Prob }>z=0.9573\end{array}$ & $\begin{array}{c}Z=-0.05 \\
\operatorname{Pr}>z=0.9588\end{array}$ \\
\hline & $\begin{array}{c}\text { Sargan Test of } \\
\text { Overid. Restriction }\end{array}$ & & Prob $>$ Chi2 $=0.082$ & Prob $>$ chi $2=0.085$ \\
\hline \multirow[t]{3}{*}{ BB } & $\begin{array}{l}A B \text { test for } A R(1) \\
\text { in first differences }\end{array}$ & $\begin{array}{c}\text { No } \\
\text { autocorrelation }\end{array}$ & $\begin{array}{c}Z=-7.47 \\
\text { Prob }>z=0.000\end{array}$ & $\begin{array}{c}Z=-7.49 \\
\text { Prob }>z=0.000\end{array}$ \\
\hline & $\begin{array}{l}A B \text { test for } A R(2) \\
\text { in first differences }\end{array}$ & $\begin{array}{c}\text { No } \\
\text { autocorrelation }\end{array}$ & $\begin{array}{c}Z=0.01 \\
\text { Prob }>z=0.990\end{array}$ & $\begin{array}{c}Z=0.04 \\
\text { Prob }>z=0.965\end{array}$ \\
\hline & $\begin{array}{c}\text { Sargan Test of } \\
\text { Overid. } \\
\text { restrictions }\end{array}$ & & $\begin{array}{c}\text { Chi2 }(169)=285.83 \\
\text { Prob }>\text { chi } 2=0.034\end{array}$ & $\begin{array}{l}\text { Chi2 }(169)=639.18 \\
\text { Prob }>\text { chi2 }=0.006\end{array}$ \\
\hline
\end{tabular}

\begin{tabular}{|c|c|c|c|c|}
\hline \multicolumn{5}{|c|}{ Hypothesis 2.1} \\
\hline Estimator & Test & $\mathrm{HO}$ & I & II \\
\hline \multirow[t]{3}{*}{$A B$} & $\begin{array}{c}1^{\text {st }} \text { order } \\
\text { autocorrelation }\end{array}$ & $\begin{array}{c}\text { No } \\
\text { autocorrelation }\end{array}$ & $\begin{array}{c}Z=-7.35 \\
\text { Prob }>z=0.000\end{array}$ & $\begin{array}{c}Z=-7.33 \\
\operatorname{Pr}>z=0.000\end{array}$ \\
\hline & $\begin{array}{c}2^{\text {nd }} \text { order } \\
\text { autocorrelation }\end{array}$ & $\begin{array}{c}\text { No } \\
\text { autocorrelation }\end{array}$ & $\begin{array}{c}Z=-0.62 \\
\text { Prob }>z=0.5379\end{array}$ & $\begin{array}{c}Z=-0.60 \\
\operatorname{Pr}>z=0.5502\end{array}$ \\
\hline & $\begin{array}{c}\text { Sargan Test of } \\
\text { Overid. Restriction }\end{array}$ & & Prob $>$ Chi2 $=0.001$ & Prob $>$ chi $2=0.002$ \\
\hline \multirow[t]{3}{*}{ BB } & $\begin{array}{l}A B \text { test for } A R(1) \\
\text { in first differences }\end{array}$ & $\begin{array}{c}\text { No } \\
\text { autocorrelation }\end{array}$ & $\begin{array}{c}Z=-7.73 \\
\text { Prob }>z=0.000\end{array}$ & $\begin{array}{c}Z=-7.72 \\
\text { Prob }>z=0.000\end{array}$ \\
\hline & $\begin{array}{l}A B \text { test for } A R(2) \\
\text { in first differences }\end{array}$ & $\begin{array}{c}\text { No } \\
\text { autocorrelation }\end{array}$ & $\begin{array}{c}Z=-0.79 \\
\text { Prob }>z=0.428\end{array}$ & $\begin{array}{c}Z=-0.58 \\
\text { Prob }>z=0.562\end{array}$ \\
\hline & $\begin{array}{l}\text { Sargan Test of } \\
\text { Overid. } \\
\text { restrictions }\end{array}$ & & $\begin{array}{c}\text { Chi2 }(169)=438.85 \\
\text { Prob }>\text { chi2 }=0.000\end{array}$ & $\begin{array}{l}\text { Chi2 }(169)=639.18 \\
\text { Prob }>\text { chi2 }=0.004\end{array}$ \\
\hline
\end{tabular}




\begin{tabular}{|c|c|c|c|c|}
\hline \multicolumn{5}{|c|}{ Hypothesis 3} \\
\hline Estimator & Test & $\mathrm{HO}$ & I & II \\
\hline \multirow[t]{3}{*}{$A B$} & $\begin{array}{c}1^{\text {st }} \text { order } \\
\text { autocorrelation }\end{array}$ & $\begin{array}{c}\text { No } \\
\text { autocorrelation }\end{array}$ & $\begin{array}{c}Z=-9.42 \\
\text { Prob }>z=0.000\end{array}$ & $\begin{array}{c}Z=-8.77 \\
\operatorname{Pr}>z=0.000\end{array}$ \\
\hline & $\begin{array}{c}2^{\text {nd }} \text { order } \\
\text { autocorrelation }\end{array}$ & $\begin{array}{c}\text { No } \\
\text { autocorrelation }\end{array}$ & $\begin{array}{c}\mathrm{Z}=-1.57 \\
\text { Prob }>\mathrm{z}=0.1153\end{array}$ & $\begin{array}{c}Z=-1.69 \\
\operatorname{Pr}>z=0.0915\end{array}$ \\
\hline & $\begin{array}{c}\text { Sargan Test of } \\
\text { Overid. Restriction }\end{array}$ & & Prob $>$ Chi2 $=0.2677$ & Prob $>$ chi2 $=0.2366$ \\
\hline \multirow[t]{3}{*}{ BB } & $\begin{array}{l}A B \text { test for } A R(1) \\
\text { in first differences }\end{array}$ & $\begin{array}{c}\text { No } \\
\text { autocorrelation }\end{array}$ & $\begin{array}{c}Z=-6.44 \\
\text { Prob }>z=0.000\end{array}$ & $\begin{array}{c}Z=-6.60 \\
\text { Prob }>z=0.000\end{array}$ \\
\hline & $\begin{array}{l}A B \text { test for } A R(2) \\
\text { in first differences }\end{array}$ & $\begin{array}{c}\text { No } \\
\text { autocorrelation }\end{array}$ & $\begin{array}{c}Z=-0.69 \\
\text { Prob }>z=0.491\end{array}$ & $\begin{array}{c}Z=-0.70 \\
\text { Prob }>z=0.4855\end{array}$ \\
\hline & $\begin{array}{l}\text { Sargan Test of } \\
\text { Overid. } \\
\text { restrictions }\end{array}$ & & $\begin{array}{c}\text { Chi2 }(169)=219.77 \\
\text { Prob }>\text { chi2 }=0.000\end{array}$ & $\begin{array}{l}\text { Chi2 }(169)=223.63 \\
\text { Prob }>\text { chi2 }=0.004\end{array}$ \\
\hline
\end{tabular}

\begin{tabular}{|c|c|c|c|c|}
\hline \multicolumn{5}{|c|}{ Hypothesis 6} \\
\hline Estimator & Test & $\mathrm{HO}$ & $\mathrm{I}$ & II \\
\hline \multirow[t]{3}{*}{$A B$} & $\begin{array}{c}1^{\text {st }} \text { order } \\
\text { autocorrelation }\end{array}$ & $\begin{array}{c}\text { No } \\
\text { autocorrelation }\end{array}$ & $\begin{array}{c}Z=-5.81 \\
\text { Prob }>z=0.000\end{array}$ & $\begin{array}{c}Z=-5.83 \\
\operatorname{Pr}>z=0.000\end{array}$ \\
\hline & $\begin{array}{c}2^{\text {nd }} \text { order } \\
\text { autocorrelation }\end{array}$ & $\begin{array}{c}\text { No } \\
\text { autocorrelation }\end{array}$ & $\begin{array}{c}Z=-0.40 \\
\text { Prob }>z=0.1153\end{array}$ & $\begin{array}{c}Z=0.70 \\
\operatorname{Pr}>Z=0.4845\end{array}$ \\
\hline & $\begin{array}{c}\text { Sargan Test of } \\
\text { Overid. Restriction }\end{array}$ & & Prob $>$ Chi2 $=0.0004$ & Prob $>$ chi $2=0.0457$ \\
\hline \multirow[t]{3}{*}{ BB } & $\begin{array}{l}A B \text { test for } A R(1) \\
\text { in first differences }\end{array}$ & $\begin{array}{c}\text { No } \\
\text { autocorrelation }\end{array}$ & $\begin{array}{c}Z=-5.43 \\
\text { Prob }>z=0.000\end{array}$ & $\begin{array}{c}Z=-5.76 \\
\text { Prob }>z=0.000\end{array}$ \\
\hline & $\begin{array}{l}A B \text { test for } A R(2) \\
\text { in first differences }\end{array}$ & $\begin{array}{c}\text { No } \\
\text { autocorrelation }\end{array}$ & $\begin{array}{c}Z=-0.04 \\
\text { Prob }>z=0.969\end{array}$ & $\begin{array}{c}Z=-0.45 \\
\text { Prob }>z=0.655\end{array}$ \\
\hline & $\begin{array}{c}\text { Sargan Test of } \\
\text { Overid. } \\
\text { restrictions }\end{array}$ & & $\begin{array}{c}\text { Chi2 }(169)=289.90 \\
\text { Prob }>\text { chi } 2=0.004\end{array}$ & $\begin{array}{l}\text { Chi } 2(169)=220.63 \\
\text { Prob }>\text { chi2 }=0.002\end{array}$ \\
\hline
\end{tabular}

\begin{tabular}{|c|c|c|c|c|}
\hline \multicolumn{5}{|c|}{ Hypothesis 6.1} \\
\hline Estimator & Test & $\mathrm{HO}$ & 1 & II \\
\hline \multirow[t]{3}{*}{$A B$} & $\begin{array}{c}1^{\text {st }} \text { order } \\
\text { autocorrelation }\end{array}$ & $\begin{array}{c}\text { No } \\
\text { autocorrelation }\end{array}$ & $\begin{array}{c}Z=-6.37 \\
\text { Prob }>z=0.000\end{array}$ & $\begin{array}{c}Z=-6.29 \\
\operatorname{Pr}>z=0.000\end{array}$ \\
\hline & $\begin{array}{c}2^{\text {nd }} \text { order } \\
\text { autocorrelation }\end{array}$ & $\begin{array}{c}\text { No } \\
\text { autocorrelation }\end{array}$ & $\begin{array}{c}\mathrm{Z}=-0.86 \\
\text { Prob }>z=0.3907\end{array}$ & $\begin{array}{c}Z=-0.69 \\
\operatorname{Pr}>z=0.492\end{array}$ \\
\hline & $\begin{array}{c}\text { Sargan Test of } \\
\text { Overid. Restriction }\end{array}$ & & Prob $>$ Chi2 $=0.876$ & Prob $>$ chi2 $=0.821$ \\
\hline \multirow[t]{3}{*}{ BB } & $\begin{array}{l}A B \text { test for } A R(1) \\
\text { in first differences }\end{array}$ & $\begin{array}{c}\text { No } \\
\text { autocorrelation }\end{array}$ & $\begin{array}{c}Z=-6.85 \\
\text { Prob }>z=0.000\end{array}$ & $\begin{array}{c}Z=-6.73 \\
\text { Prob }>z=0.000\end{array}$ \\
\hline & $\begin{array}{l}A B \text { test for } A R(2) \\
\text { in first differences }\end{array}$ & $\begin{array}{c}\text { No } \\
\text { autocorrelation }\end{array}$ & $\begin{array}{c}Z=-0.94 \\
\text { Prob }>z=0.346\end{array}$ & $\begin{array}{c}Z=-0.56 \\
\text { Prob }>z=0.576\end{array}$ \\
\hline & $\begin{array}{c}\text { Sargan Test of } \\
\text { Overid. } \\
\text { restrictions }\end{array}$ & & $\begin{array}{c}\text { Chi2 }(169)=100.52 \\
\text { Prob }>\text { chi } 2=0.856\end{array}$ & $\begin{array}{l}\text { Chi2 }(169)=107.53 \\
\text { Prob }>\text { chi2 }=0.842\end{array}$ \\
\hline
\end{tabular}




\begin{tabular}{|c|c|c|c|c|}
\hline \multicolumn{5}{|c|}{ Hypothesis 7} \\
\hline Estimator & Test & $\mathrm{HO}$ & I & II \\
\hline \multirow[t]{3}{*}{$A B$} & $\begin{array}{c}1^{\text {st }} \text { order } \\
\text { autocorrelation }\end{array}$ & $\begin{array}{c}\text { No } \\
\text { autocorrelation }\end{array}$ & $\begin{array}{c}Z=-9.01 \\
\text { Prob }>z=0.000\end{array}$ & $\begin{array}{c}Z=-8.99 \\
\operatorname{Pr}>z=0.000\end{array}$ \\
\hline & $\begin{array}{c}2^{\text {nd }} \text { order } \\
\text { autocorrelation }\end{array}$ & $\begin{array}{c}\text { No } \\
\text { autocorrelation }\end{array}$ & $\begin{array}{c}Z=3.15 \\
\text { Prob }>z=0.095\end{array}$ & $\begin{array}{c}Z=3.04 \\
\operatorname{Pr}>z=0.156\end{array}$ \\
\hline & $\begin{array}{c}\text { Sargan Test of } \\
\text { Overid. Restriction }\end{array}$ & & Prob $>$ Chi2 $=0.184$ & Prob $>$ chi2 $=0.130$ \\
\hline \multirow[t]{3}{*}{$\mathrm{BB}$} & $\begin{array}{l}A B \text { test for } A R(1) \\
\text { in first differences }\end{array}$ & $\begin{array}{c}\text { No } \\
\text { autocorrelation }\end{array}$ & $\begin{array}{c}Z=-10.15 \\
\text { Prob }>z=0.000\end{array}$ & $\begin{array}{c}Z=-9.96 \\
\text { Prob }>z=0.000\end{array}$ \\
\hline & $\begin{array}{l}A B \text { test for } A R(2) \\
\text { in first differences }\end{array}$ & $\begin{array}{c}\text { No } \\
\text { autocorrelation }\end{array}$ & $\begin{array}{c}Z=-0.55 \\
\text { Prob }>z=0.584\end{array}$ & $\begin{array}{c}Z=0.70 \\
\text { Prob }>z=0.485\end{array}$ \\
\hline & $\begin{array}{c}\text { Sargan Test of } \\
\text { Overid. } \\
\text { restrictions }\end{array}$ & & $\begin{aligned} \text { Chi2 }(169) & =163.04 \\
\text { Prob }>\text { chi2 } & =0.062\end{aligned}$ & $\begin{array}{l}\text { Chi2 }(169)=220.63 \\
\text { Prob }>\text { chi2 }=0.059\end{array}$ \\
\hline
\end{tabular}

\begin{tabular}{|c|c|c|c|c|}
\hline \multicolumn{5}{|c|}{ Hypothesis 8} \\
\hline Estimator & Test & $\mathrm{HO}$ & 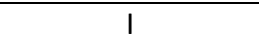 & II \\
\hline \multirow[t]{3}{*}{$A B$} & $\begin{array}{c}1^{\text {st }} \text { order } \\
\text { autocorrelation }\end{array}$ & $\begin{array}{c}\text { No } \\
\text { autocorrelation }\end{array}$ & $\begin{array}{c}Z=-9.94 \\
\text { Prob }>z=0.000\end{array}$ & $\begin{array}{c}Z=-8.99 \\
P r>Z=0.000\end{array}$ \\
\hline & $\begin{array}{c}2^{\text {nd }} \text { order } \\
\text { autocorrelation }\end{array}$ & $\begin{array}{c}\text { No } \\
\text { autocorrelation }\end{array}$ & $\begin{array}{c}Z=0.13 \\
\text { Prob }>z=0.098\end{array}$ & $\begin{array}{c}Z=1.91 \\
\operatorname{Pr}>z=0.087\end{array}$ \\
\hline & $\begin{array}{c}\text { Sargan Test of } \\
\text { Overid. Restriction }\end{array}$ & & Prob $>$ Chi2 $=0.053$ & Prob $>$ chi2 $=0.0457$ \\
\hline \multirow[t]{3}{*}{ BB } & $\begin{array}{l}A B \text { test for } A R(1) \\
\text { in first differences }\end{array}$ & $\begin{array}{c}\text { No } \\
\text { autocorrelation }\end{array}$ & $\begin{array}{c}Z=-10.37 \\
\text { Prob }>z=0.000\end{array}$ & $\begin{array}{c}Z=-10.54 \\
\text { Prob }>z=0.000\end{array}$ \\
\hline & $\begin{array}{l}A B \text { test for } A R(2) \\
\text { in first differences }\end{array}$ & $\begin{array}{c}\text { No } \\
\text { autocorrelation }\end{array}$ & $\begin{array}{c}Z=-0.75 \\
\text { Prob }>z=0.610\end{array}$ & $\begin{array}{c}Z=0.70 \\
\text { Prob }>z=0.485\end{array}$ \\
\hline & $\begin{array}{c}\text { Sargan Test of } \\
\text { Overid. } \\
\text { restrictions }\end{array}$ & & $\begin{array}{c}\text { Chi2 }(169)=220.63 \\
\text { Prob }>\text { chi2 }=0.004\end{array}$ & $\begin{array}{l}\text { Chi2(169) }=131.20 \\
\text { Prob }>\text { chi2 }=0.032\end{array}$ \\
\hline
\end{tabular}

